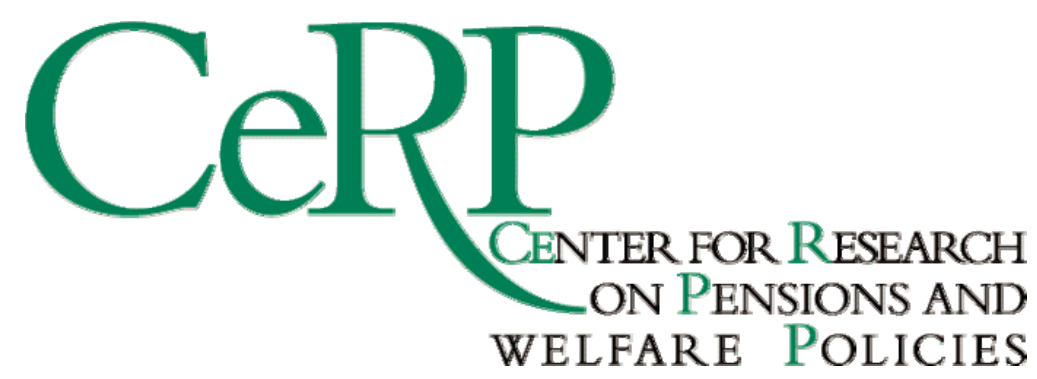

Working Paper 128/12

DETERMINANTS OF US FINANCIAL FRAGILITY CONDITIONS

\author{
Fabio Cesare Bagliano
}

Claudio Morana 


\title{
Determinants of US financial fragility conditions*
}

\author{
Fabio C. Bagliano \\ Università di Torino and CeRP-Collegio Carlo Alberto \\ Claudio Morana \\ Università di Milano Bicocca, CeRP-Collegio Carlo Alberto, \\ Fondazione Eni Enrico Mattei (Milano) and ICER (Torino) \\ Revised draft: August 2012
}

\begin{abstract}
The recent financial crisis has highlighted the fragility of the US (and other countries') financial system under several respects. In this paper, the properties of a summary index of financial fragility, obtained by combining information conveyed by the "Agency", "Ted" and "BAA-AAA" spreads, timely capturing changes in credit and liquidity risk, distress in the mortgage market, and corporate default risk, are investigated over the 1986-2010 period. The empirical results show that observed fluctuations in the financial fragility index can be attributed to identified (global and domestic) macroeconomic $(20 \%)$ and financial disturbances ( $40 \%$ to $50 \%$ ), over both short- and longterm horizons, as well as to oil-supply shocks in the long-term (25\%). The investigation of specific episodes of financial distress, occurred in 1987, 1998 and 2000, and, more recently, over the 2007-2009 period, shows that sizable fluctuations in the index are largely determined by financial shocks, while macroeconomic disturbances have generally had a stabilizing effect.

Keywords: financial fragility, US, macro-finance interface, international business cycle, factor vector autoregressive models, financial crisis, Great Recession

JEL classification: C22; E32; G12
\end{abstract}

${ }^{*}$ Acknowledgements. Financial support from MIUR (PRIN project) is gratefully acknowledged. 


\section{Introduction}

As recent global macroeconomic and financial events have powerfully shown, strong interlinkages relate financial and macroeconomic dynamics, also across countries, due to financial and economic integration. Indeed, the 2007-2008 financial crisis and the ensuing "Great Recession" is an important example of a domestic (US) financial crisis, whose depressive effects quickly spilled over worldwide, amplified by the leading role of the US economy. The originating mechanism of the crisis can be traced back to excess debt creation in the US subprime mortgage market, leading to a boom-bust cycle in credit volumes and house and stock prices. Procyclical bank loans, a benign price stability environment, accommodative monetary policy, growing external debt, and deregulated financial markets all worked as amplifying mechanisms (see Bagliano and Morana, 2012 for a recent account of the crisis).

One of the likely reasons for the unprecedented depth of the crisis is the mounting fragility of the US financial sector, associated with excessive leverage and overstretching of credit. Such a phenomenon presents a number of different but interrelated dimensions, involving, among others, credit and liquidity risk conditions, the amount of stress in the mortgage market and corporate default risk perceptions. A summary measure of financial market conditions is not readily available, many indicators providing useful information on specific aspects of the financial system's state of health.

In this paper we analyze the properties of the synthetic index of US economic and financial fragility proposed by Bagliano and Morana (2012), obtained by combining the information conveyed by several indicators (return differentials) that are closely scrutinized by financial economists, professionals and policymakers. Specifically, we employ a Factor Vector Autoregressive model to assess the relative importance of global (worldwide) and domestic (US) factors in determining fluctuations of the proposed US financial fragility measure over the 1986-2010 period.

The global factors include unobserved driving forces extracted from a large set of macroeconomic and financial quantities covering 50 countries and capturing worldwide developments in a wide range of real activity, labor market, liquidity, interest rates and financial price variables. In addition, a number of domestic variables are included in order to account for several sources of US financial disturbances and fundamental economic imbalances. Finally, a set of variables concerning global oil demand and supply conditions are added to allow for potential effects of oil market developments on US economic and financial conditions.

To preview the main results of the paper, we find that the bulk of fluctuations in the financial fragility index can be attributed to identified macroeco- 
nomic, financial (of both a global and local nature) and oil market structural disturbances, over both short- and long-term (10-year) horizons. Fundamental financial shocks yield the largest contribution, accounting for about half of the index variability in the short-term and $40 \%$ over the 10 -year horizon, whereas the corresponding figures for macroeconomic disturbances are $25 \%$ and $15 \%$, and $5 \%$ and $25 \%$ for oil market supply side disturbances. Moreover, the analysis of specific episodes of financial distress, occurred in 1987, 1998 and 2000, and, more recently, over the 2007-2009 period, shows that sizable fluctuations in the index are largely determined by fundamental financial shocks (risk factors shocks in particular), while macroeconomic disturbances have generally had a stabilizing effect on the fragility index. Actually, consistent with the Great Moderation phenomenon, macroeconomic shocks had a stabilizing impact on the fragility index until the occurrence of the recent financial crisis, dominating over financial shocks until the mid 1990s, and offsetting the latter thereafter.

The rest of the paper is organized as follows. In Section 2 the econometric methodology is outlined, while Section 3 describes the construction of the US financial fragility index and the data used to model the most relevant global and local factors determining its behavior. Section 4 discusses specification issues, and Section 5 presents empirical results. Finally, the main conclusions are drawn in Section 6.

\section{Econometric methodology}

The econometric model is composed of two blocks of equations. The former describes the dynamics of the main macroeconomic and financial determinants of an index capturing US financial system's fragility conditions (presented in detail in the following section), including both unobserved global factors and observed US variables. The second block, which is used in order to estimate the unobserved global macro-financial factors, captures the dynamics of the main macroeconomic and financial variables for a large set of developed and emerging economies.

\subsection{The econometric model}

The first set of equations is composed of a number of unobserved $\left(\mathbf{F}_{1, t}\right)$ and observed $\left(\mathbf{F}_{2, t}\right)$ global macro-financial factors and oil market demand and

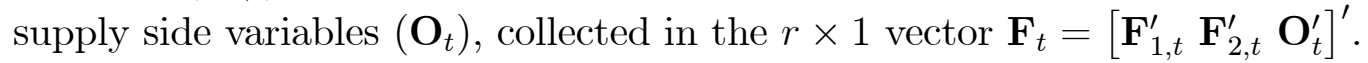
The second block of equations refers to $q$ macro-financial variables for each of $m$ countries (for a total of $n=m \times q$ equations). The joint dynamics of 
the global macro-finance-oil market factors and the country-specific macrofinance interactions are then modelled by means of the following reduced form dynamic factor model

$$
\begin{aligned}
(\mathbf{I}-\mathbf{P}(L))\left(\mathbf{F}_{t}-\boldsymbol{\kappa}_{t}\right) & =\boldsymbol{\eta}_{t} \\
(\mathbf{I}-\mathbf{C}(L))\left(\left(\mathbf{Z}_{t}-\boldsymbol{\mu}_{t}\right)-\boldsymbol{\Lambda}\left(\mathbf{F}_{t}-\boldsymbol{\kappa}_{t}\right)\right) & =\mathbf{v}_{t} .
\end{aligned}
$$

The model is cast in a weakly stationary representation, as $\left(\mathbf{F}_{t}-\boldsymbol{\kappa}_{t}\right),\left(\mathbf{Z}_{t}-\right.$ $\left.\boldsymbol{\mu}_{t}\right) \sim I(0)$, where $\boldsymbol{\mu}_{t}$ and $\boldsymbol{\kappa}_{t}$ are $n \times 1$ and $r \times 1$ vectors of deterministic components, respectively, with $r \leq n$, including an intercept, and, possibly, linear or non linear trend terms. Global dynamics are described by the stationary finite order polynomial matrix in the lag operator $\mathbf{P}(L), \mathbf{P}(L) \equiv$ $\mathbf{P}_{1} L+\mathbf{P}_{2} L^{2}+\ldots+\mathbf{P}_{p} L^{p}$, where $\mathbf{P}_{j}, j=1, . ., p$, is a square matrix of coefficients of order $r$, and $\boldsymbol{\eta}_{t} \sim$ i.i.d. $\left(\mathbf{0}, \boldsymbol{\Sigma}_{\eta}\right)$ is a $r \times 1$ vector of reduced form shocks driving the $\mathbf{F}_{t}$ factors. The contemporaneous effects of the global factors on each country variables in $\mathbf{Z}_{t}$ are measured by the loading coefficients collected in the $n \times r$ matrix $\boldsymbol{\Lambda}=\left[\boldsymbol{\Lambda}_{F_{1}}^{\prime} \boldsymbol{\Lambda}_{F_{2}}^{\prime} \boldsymbol{\Lambda}_{O}^{\prime}\right]^{\prime}$. Finally, $\mathbf{v}_{t} \sim$ i.i.d. $\left(\mathbf{0}, \boldsymbol{\Sigma}_{v}\right)$ is the $n \times 1$ vector of reduced-form idiosyncratic (i.e. country-specific) disturbances, with $E\left[\eta_{j t} v_{i s}\right]=0$ for all $i, j, t, s$, and $\mathbf{C}(L)$ is a finite order stationary block diagonal polynomial matrix in the lag operator, $\mathbf{C}(L) \equiv \mathbf{C}_{1} L+\mathbf{C}_{2} L^{2}+\ldots+$ $\mathbf{C}_{c} L^{c}$, where $\mathbf{C}_{j}, j=0, . ., c$, is a square matrix of coefficients of order $n$, partitioned as

$$
\underset{n \times n}{\mathbf{C}_{j}}=\left[\begin{array}{cccc}
\mathbf{C}_{j, 11} & \mathbf{0} & \ldots & \mathbf{0} \\
q \times q & & & \\
\mathbf{0} & \mathbf{C}_{j, 22} & \ldots & \mathbf{0} \\
& q \times q & & \\
\vdots & \ldots & \ddots & \vdots \\
\mathbf{0} & \mathbf{0} & \ldots & \mathbf{C}_{j, m m} \\
& & & \substack{q \times q\\
}
\end{array}\right]
$$

The specification of the model in (1)-(2) embeds a set of important assumptions on the structure of global and local linkages: $(i)$ global shocks $\left(\boldsymbol{\eta}_{t}\right)$ affect both the global and local economy through the polynomial matrix $\mathbf{P}(L)$ and the factor loading matrix $\boldsymbol{\Lambda}$; (ii) country-specific disturbances $\left(\mathbf{v}_{t}\right)$ do not affect global factor dynamics, limiting their impact only to the country of origin $(\mathbf{C}(L)$ is assumed to be block (own-country) diagonal).

By substituting (1) into (2), the reduced form vector autoregressive (VAR) representation of the dynamic factor model can be written as

$$
(\mathbf{I}-\mathbf{A}(L))\left(\mathbf{Y}_{t}-\gamma_{t}\right)=\varepsilon_{t}
$$


where $\mathbf{Y}_{t}=\left[\begin{array}{ll}\mathbf{F}_{t}^{\prime} & \mathbf{Z}_{t}^{\prime}\end{array}\right]^{\prime}, \boldsymbol{\gamma}_{t}=\left[\boldsymbol{\kappa}_{t}^{\prime} \boldsymbol{\mu}_{t}^{\prime}\right]^{\prime}$,

$$
\begin{gathered}
\mathbf{A}(L)=\left(\begin{array}{cc}
\mathbf{P}(L) & \mathbf{0} \\
{[\boldsymbol{\Lambda} \mathbf{P}(L)-\mathbf{C}(L) \boldsymbol{\Lambda}]} & \mathbf{C}(L)
\end{array}\right), \\
\boldsymbol{\varepsilon}_{t} \equiv\left[\begin{array}{l}
\boldsymbol{\varepsilon}_{1, t} \\
\boldsymbol{\varepsilon}_{2, t}
\end{array}\right]=\left[\begin{array}{c}
\mathbf{I} \\
\boldsymbol{\Lambda}
\end{array}\right]\left[\boldsymbol{\eta}_{t}\right]+\left[\begin{array}{c}
\mathbf{0} \\
\mathbf{v}_{t}
\end{array}\right],
\end{gathered}
$$

with variance-covariance matrix

$$
E\left[\varepsilon_{t} \varepsilon_{t}^{\prime}\right]=\Sigma_{\varepsilon}=\left(\begin{array}{cc}
\Sigma_{\eta} & \Sigma_{\eta} \Lambda^{\prime} \\
\Lambda \Sigma_{\eta} & \Lambda \Sigma_{\eta} \Lambda^{\prime}+\Sigma_{v}
\end{array}\right)
$$

\subsection{Estimation}

The model is estimated by means of a two-stage approach. First, consistent and asymptotically normal estimation of the set of equations in (2) is obtained following the iterative procedure proposed in Morana (2011); the latter bears the interpretation of $Q M L$ estimation performed by means of the EM algorithm. In the $E$-step the unobserved factors $\left(\mathbf{F}_{1, t}\right)$ are estimated, given the observed data and the current estimate of model parameters, by means of principal components analysis $(P C A)$; in the $M$-step the likelihood function is maximized (OLS estimation of the $\mathbf{C}(L)$ matrix is performed) under the assumption that the unobserved factors are known, conditioning on their $E$-step estimate. Convergence to the one-step $Q M L$ estimate is ensured, as the value of the likelihood function is increased at each step.

The iterative procedure can be described as follows:

- An initial estimate of the $r_{1}$ unobserved common factors in $\mathbf{F}_{1, t}$ is obtained through the application of Principal Components Analysis (PCA) to subsets of homogeneous cross-country data $\mathbf{Z}_{i}=\left\{\mathbf{Z}_{i, 1}, \ldots, \mathbf{Z}_{i, T}\right\}$, $i=1, \ldots, r_{1}, r_{1} \leq q ;^{1}$ then, an initial estimate of the polynomial matrix $\mathbf{C}(L)$ and the factor loading matrix $\Lambda$ is obtained by means of OLS estimation of the equation system in (2). This is performed by first regressing $\hat{\mathbf{F}}_{t}$ on $\boldsymbol{\kappa}_{t}$ to obtain $\hat{\boldsymbol{\kappa}}_{t}$; then the actual series $\mathbf{Z}_{t}$ are regressed on $\boldsymbol{\mu}_{t}$ and $\hat{\mathbf{F}}_{t}-\hat{\boldsymbol{\kappa}}_{t}$ to obtain $\hat{\boldsymbol{\Lambda}}$ and $\hat{\boldsymbol{\mu}}_{t} ; \hat{\mathbf{C}}(L)$ is then obtained by means of OLS estimation of the VAR model for the gap variables $\mathbf{Z}_{t}-\hat{\boldsymbol{\mu}}_{t}-\hat{\boldsymbol{\Lambda}}\left(\hat{\mathbf{F}}_{t}-\hat{\boldsymbol{\kappa}}_{t}\right)$ in $(2)$;

\footnotetext{
${ }^{1}$ For instance, a stock return global factor can be estimated by means of the application of PCA to the vector of cross-country stock return data, and so on.
} 
- then, a new estimate of the unobserved factors $\mathbf{F}_{1, t}$ is obtained by means of PCA applied to the filtered series $\mathbf{Z}_{t}^{*}=\mathbf{Z}_{t}-[\mathbf{I}-\hat{\mathbf{C}}(L)] \hat{\boldsymbol{\Lambda}}_{*}\left(\hat{\mathbf{F}}_{*, t}-\hat{\boldsymbol{\kappa}}_{*, t}\right)$, with $\hat{\mathbf{F}}_{*, t}=\left[\begin{array}{ll}\mathbf{F}_{2, t}^{\prime} & \mathbf{O}_{t}^{\prime}\end{array}\right]^{\prime}, \hat{\boldsymbol{\Lambda}}_{*}=\left[\begin{array}{ll}\hat{\boldsymbol{\Lambda}}_{F_{2}}^{\prime} & \hat{\boldsymbol{\Lambda}}_{O}^{\prime}\end{array}\right]^{\prime}$ and $\hat{\boldsymbol{\kappa}}_{*, t}=\left[\hat{\boldsymbol{\kappa}}_{F_{2}, t}^{\prime} \hat{\boldsymbol{\kappa}}_{O, t}^{\prime}\right]^{\prime}$;

- next, a new estimate of the polynomial matrix $\mathbf{C}(L)$ and the factor loading matrix $\boldsymbol{\Lambda}$ is obtained as described in the initialization step. The iterative procedure is then repeated until convergence.

In the second stage of the procedure, consistent and asymptotically normal estimation of the set of equations in (1) is performed by means of PC-VAR estimation (Morana, 2012), treating the consistently estimated factors as observed. The latter is achieved in the following steps:

- PCA is applied to $\mathbf{x}_{t} \equiv \hat{\mathbf{F}}_{t}-\hat{\boldsymbol{\kappa}}_{t}$ and the first $s$ PCs, $\hat{\mathbf{f}}_{t}$, are computed;

- the dynamic vector regression

$$
\begin{aligned}
\mathbf{x}_{t} & =\mathbf{D}(L) \hat{\mathbf{f}}_{t}+\boldsymbol{\varsigma}_{t} \\
\boldsymbol{\varsigma}_{t} & \sim \text { I.I.D. }\left(\mathbf{0}, \boldsymbol{\Sigma}_{\varsigma}\right),
\end{aligned}
$$

where $\mathbf{D}(L) \equiv \mathbf{D}_{1} L+\mathbf{D}_{2} L^{2}+\ldots+\mathbf{D}_{p} L^{p}$ has all the roots outside the unit circle, is estimated by OLS to obtain $\hat{\mathbf{D}}(L)$;

- the (implied OLS) estimate of the VAR parameters in (1) is then obtained by solving

$$
\hat{\mathbf{P}}(L)_{P C V A R}=\hat{\mathbf{D}}(L) \hat{\mathbf{\Xi}}_{s}^{\prime},
$$

where $\hat{\boldsymbol{\Xi}}_{s}$ is the matrix of the eigenvectors associated with the first $s$ ordered eigenvalues of $\hat{\boldsymbol{\Sigma}}\left(\boldsymbol{\Sigma}=E\left[\mathbf{x}_{t} \mathbf{x}_{t}^{\prime}\right]\right)$.

\subsection{Dynamic analysis}

The structural vector moving average representation for the global model in (1) can be written as

$$
\left(\mathbf{F}_{t}-\boldsymbol{\kappa}_{t}\right)=\mathbf{H}_{F}(L) \mathbf{K}^{-1} \boldsymbol{\xi}_{t},
$$


where $\boldsymbol{\xi}_{t}$ is the vector of the $r$ structural shocks driving the common factors in $\mathbf{F}_{t}$, i.e. $\boldsymbol{\xi}_{t}=\mathbf{K} \boldsymbol{\eta}_{t}, \mathbf{K}$ is a $r \times r$ invertible matrix, and

$$
\mathbf{H}(L) \equiv\left(\begin{array}{cc}
\mathbf{H}_{F}(L) & \mathbf{0} \\
\mathbf{H}_{F Z}(L) & \mathbf{H}_{Z}(L)
\end{array}\right) \equiv(\mathbf{I}-\mathbf{A}(L))^{-1} .
$$

By assumption the structural factor shocks are orthogonal and have unit variance, so that $E\left[\boldsymbol{\xi}_{t} \boldsymbol{\xi}_{t}^{\prime}\right]=\mathbf{K} \boldsymbol{\Sigma}_{\eta} \mathbf{K}^{\prime}=\mathbf{I}_{r}$. To achieve exact identification of the structural disturbances, additional $r(r-1) / 2$ restrictions need to be imposed. Since $\boldsymbol{\eta}_{t}=\mathbf{K}^{-1} \boldsymbol{\xi}_{t}$, imposing exclusion restrictions on the contemporaneous impact matrix amounts to imposing zero restrictions on the elements of $\mathbf{K}^{-1}$, for which a lower-triangular structure is assumed. This latter assumption implies a precise "ordering" of the common factors in $\mathbf{F}_{t}$. In particular, the first factor is allowed to have a contemporaneous impact on all other factors, but reacts only with a one-period lag to the other structural disturbances; instead, the last factor is contemporaneously affected by all structural shocks, having only lagged effects on all other factors. Operationally, $\mathbf{K}^{-1}$ (with the $r(r-1) / 2$ zero restrictions necessary for exact identification imposed) is estimated by the Choleski decomposition of the factor innovation variance-covariance matrix $\boldsymbol{\Sigma}_{\eta}$, i.e. $\hat{\mathbf{K}}^{-1}=\operatorname{chol}\left(\hat{\boldsymbol{\Sigma}}_{\eta}\right)$.

Forecast error variance and historical decompositions can then be obtained by means of standard formulas. Following the thick modelling strategy of Granger and Jeon (2004), median estimates of the parameters of interest, impulse responses, forecast error variance and historical decompositions, as well as their confidence intervals, robust to model misspecification, can be obtained by means of simulated implementation of the proposed estimation strategy. See Morana $(2011,2012)$ for a detailed account of the econometric methodology.

\section{The data}

In this section we briefly describe the construction of the index of US financial fragility, and the global and local factors that we use in our empirical analysis.

\subsection{A US financial fragility index}

In order to investigate the relative importance of global and local factors as determinants of US financial conditions, an index intended to capture financial distress in US markets is constructed, summarizing information from three widely used indicators. In particular, following Bagliano and Morana (2012), we look at the TED spread, i.e. the differential between the 3-month 
LIBOR rate (Euro dollar deposit rate) and the yield on 3-month Treasury bills; being the difference between an unsecured deposit rate and a risk-free rate, the $T E D$ spread can be taken as a measure of credit and liquidity risk. Moreover, we use the $A G E N C Y$ spread between the yield on 30-year bonds issued by government-sponsored agencies (Freddie Mae and Fannie Mac) and 30-year Treasury bonds, capturing stress in the mortgage market. Finally, we look at the yield differential between $B A A$-rated and $A A A$-rated corporate bonds $(B A A-A A A)$, providing a direct measure of corporate default risk and, more generally, a measure of investors' risk-taking attitude, since a contraction of this spread signals an increase in the demand for riskier bonds relative to safer ones. As shown in Figure 1, over the 1980-2010 period, the three spreads strongly comove over the medium- to long-term, but display variations that are not perfectly correlated in the short-term (the contemporaneous quarterly correlation coefficients ranging from 0.6 to 0.74 ), suggesting that they contain different information on complementary dimensions of financial distress and perceived risk. To obtain a synthetic indicator of financial conditions, we extract the first principal component from the TED, AGENCY, and $B A A-A A A$ measures, which accounts for about $80 \%$ of the overall variability of the three spreads; the resulting variable, interpreted as an index of US financial fragility $(F R A)$, is shown in Figure 1.

The behavior of the US financial fragility index over time is the result of many different economic and financial disturbances of a global and local nature. In the following empirical analysis, three sets of factors are specifically considered: global (world-wide) factors, local (US) factors and factors related to the international oil market.

\subsection{Global factors}

First, a set of macroeconomic and financial variables is constructed in order to capture the potential effects of world-wide economic conditions on the US financial system. To this aim, we use seasonally adjusted quarterly macroeconomic time series data for 31 advanced economies, 5 advanced emerging economies and 14 secondary emerging economies, for a total of 50 countries. $^{2}$

\footnotetext{
${ }^{2}$ The advanced countries are: Australia, Austria, Belgium, Canada, Czech Republic, Denmark, Finland, France, Germany, Greece, Hong Kong, Iceland, Ireland, Israel, Italy, Japan, Luxembourg, Netherlands, New Zealand, Norway, Portugal, Singapore, Slovakia, Slovenia, South Korea, Spain, Sweden, Switzerland, Taiwan, United Kingdom. The advanced emerging economies are: Brazil, Hungary, Mexico, Poland, South Africa. The secondary emerging economies are: Argentina, Chile, China, Colombia, India, Indonesia, Malaysia, Morocco, Pakistan, Peru, Philippines, Russia, Thailand, Turkey. The main data
} 
From this large amount of time series, 12 unobserved "global" factors, driving common macro-financial dynamics in all countries, are estimated by means of the iterative procedure described in the methodological section.

In particular, global macroeconomic conditions are captured by a real activity factor $(Y)$, extracted from real GDP, private consumption and investment growth series; an employment factor $(E)$, extracted from civilian employment growth series; an unemployment rate factor $(U)$, obtained from changes in unemployment rate series; a real wage factor $(W)$, extracted from real wage growth series; a fiscal stance factor $(G)$, extracted from public expenditure to GDP ratio growth series; and a global bilateral US\$ exchange rate index $(X)$, obtained from the various bilateral exchange rates against the US\$ returns. Monetary and financial developments are captured by a nominal factor $(N)$, extracted from the inflation rate, nominal money growth, short- and long-term interest rate series; an excess liquidity index $(L)$, obtained from changes in the M3(or M2) to GDP ratio and the private loans to GDP ratio series; a real stock market price factor $(F)$, extracted from the real stock market price return series; a real housing price factor $(H)$, extracted from the real housing price return series; a real short-term rate factor $(S R)$, obtained from the real short-term interest rate series; and a term spread factor $(T S)$, extracted from the term spread series. The monetary and financial factors account for a sizeable fraction of the overall variability of the relevant component series, ranging from 30\% (in the case of the $H$ factor) to $50 \%(F)$, with the exception of the excess liquidity factor $L(15 \%)$, whereas the real activity, labor market and fiscal policy factors account for about $20 \%$ of the overall variability. For OECD countries the macro-financial sample extends from 1980(1) through 2010(3), while for non OECD countries only from 1995(1) through 2010(3); therefore, over the period 1980-1994, the above global factors reflect commonalities occurring across OECD countries only.

In addition, also two observed variables are included in the set of global influences on the US financial fragility index: the rates of change of the real gold price $(G D)$ and the IMF non-energy commodities price index $(M)$ return.

\subsection{US factors}

Along with the global factors described above, a set of 8 US variables is added to capture several sources of US financial disturbances and fundamental im-

source is IMF International Financial Statistics; other data sources are FRED2 (Federal Reserve Bank of St. Louis), the OECD and BIS (unofficial) house price data sets, and the International Energy Agency (IEA-OECD) data sets. 
balances, observed over the whole 1980(1)-2010(3) period. On the financial side, the US factors include: the Fama and French (1993) size (SMB) and value $(H M L)$ factors $^{3}$, the Carhart (1997) momentum factor $(M O M)^{4}$, the stocks' liquidity factor (PSL) proposed by Pastor and Stambaugh $(2003)^{5}$, changes in the S\&P 500 stock return volatility $(F V)$ estimated from an asymmetric GARCH $(1,1)$ model of monthly stock returns, and the leverage factor $(L E V)$ proposed by Adrian, Etula and Muir $(2011)^{6}$. Moreover, changes in the ratio of the US government budget deficit to $G D P(F d)$ and the ratio of the US trade deficit to GDP $(T d)$ have been included to capture US-specific policy and balance-of-payment factors.

\subsection{Oil market factors}

Finally, 10 variables concerning global oil demand and supply conditions have been included in order to capture potential effects of oil market developments on the US financial fragility index. In particular, we use data on world oil reserves growth $(R)$, net world oil production changes ( $P p, P m$ for positive and negative changes respectively), OECD oil refinery margins growth $(R M)$, world oil consumption $(C)$ growth, world oil inventories $(I N V)$, the rate of change of the real WTI oil price $(O P)$, changes of nominal WTI oil price volatility $(O V)$, the futures basis, i.e., the spread between the twelve-month futures and the spot oil price over the spot oil price $(F B)$, and the growth rate of the " $T$ " speculation index (WT) proposed by Working (1960). The sample for the oil market variables extends from 1986(1) through 2010(3).

\footnotetext{
${ }^{3}$ The size factor is the return differential between small and big size portfolios; the value factor is the return differential between high and low book-to-market-ratio portfolios. Adverse economic conditions should be reflected in negative changes of the size factor (small firms being more severely affected during downturns) and positive changes of the value factor (due to flight-to-quality effects, whereby investors shift from growth stocks to value stocks).

${ }^{4}$ The momentum factor is the difference between the returns on the high and low past perfomance portfolios, measured over the previous four quarters. The rationale of this factor is that, if past performance is an indicator of future returns, it can be expected to be larger over phases of economic expansion.

${ }^{5}$ The Pastor-Stambaugh liquidity factor is constructed as a cross-sectional average of individual-stock liquidity measures, the latter being the effect of the transaction volume in one month on next month individual return.

${ }^{6}$ This factor is computed as the ratio of total financial assets over the difference between total financial assets and total financial liabilities of security brokers-delears as reported in Table L.129 of the US Federal Reserve Flow of Funds. It may be considered as a proxy for financial instability, i.e. the higher the ratio, the higher the fragility of the financial sector.
} 


\section{Model specification}

The identification of the structural shocks, being the fundamental driving forces of the US financial system's conditions, has been performed by means of the Cholesky recursive identification strategy already mentioned in the methodological section, with the financial fragility index $F R A$ ordered last, and therefore being contemporaneously affected by all other structural (global, US-specific, and oil market) disturbances. The chosen ordering for the factors rests on the following set of assumptions about contemporaneous (withinquarter) reactions.

First, it is assumed that the oil market supply side variables (including reserves $R$, net oil production changes $P m$ and $P p$, and refinery margins $R M)$ are determined mainly by geophysical factors that are exogenous to macro-financial market conditions at least within the quarter. Then, the block of the above mentioned four oil supply side variables is placed first, allowing refinery margins to react within-quarter to production and reserves shocks, and production reacting to reserve disturbances only.

A set of relatively slow-moving macroeconomic variables, including both global and US-specific factors, is placed next, and therefore allowed to react contemporaneously to oil market supply side conditions. The chosen ordering goes from the global employment, unemployment, real activity, and fiscal policy factors (i.e. $E, U, Y$ and $G$ ) to the US government budget and trade deficit to GDP ratios $(F d$ and $T d$ ), and finally to the global nominal and real wage factors $(N$ and $W)$. It is then assumed that, over the business cycle, real activity is determined by labor market conditions through a short-run production function, with output growth feeding back on employment and unemployment with a (one-quarter) delay, capturing a sluggish adjustment of the labor market. Then, the global fiscal stance factor contemporaneously adjusts to business cycle conditions, showing a (one-quarter) delayed impact on real activity. The inclusion of the US fiscal and trade deficit to GDP ratios also allows us to account for two potential sources of global imbalances; both variables are assumed to contemporaneously adjust to global business cycle conditions, consistent with the fact that, though the US have largely been a net importer over the time span investigated, they still are one of the world top exporters in many industrial sectors, including machinery and equipment, motor vehicles, aircraft and food. Global aggregate demand then feeds back to global aggregate supply and prices, that adjust (through the nominal factor following in the ordering) with a one-quarter delay. Finally, real wages contemporaneously react to all aggregate demand and supply developments.

Oil consumption $C$ follows next in the ordering, based on the assumption 
that flow oil demand is contemporaneously determined by global business cycle conditions.

Finally, a set of mainly financial, relatively fast-moving, variables, comprising global and US-specific factors, is placed next, with the following ordering: excess liquidity, real short-term rate, term spread, real housing prices, and exchange rate global factors $(L, S R, T S, H$ and $X)$; they are then followed by a sub-set of US financial variables, namely stock market volatility, the size and value factors, the momentum factor, the stocks' liquidity factor, and the leverage factor $(F V, S M B, H M L, M O M, P S L$, and $L E V)$; finally, the remaining variables concerning the oil market, i.e., the Working's $\mathrm{T}$ speculative index, the futures market basis, oil inventories, the real oil price, and nominal oil price volatility (WT, FSP, INV,OP and $O V$ ), are followed by the non-energy commodities price index, the global real stock return factor, and the real gold price $(M, F$ and $G D)$.

Within this last set of variables, the selected ordering implies that the liquidity stance $(L)$, set by central banks according to the state of the business cycle, contemporaneously determines the real short-term interest rate, and affects asset prices and financial risk (captured by the size, value, momentum, stocks' liquidity and leverage factors, and stock market volatility), the latter being also a proxy for market expectations about future fundamentals. Consistent with potential leaning-against-the-wind strategies followed by monetary authorities, liquidity is allowed to react to asset prices and financial risk developments only with a (one-quarter) delay. Oil inventories $(I N V)$ contemporaneously respond to different real and financial factors, and become the transmission channel of financial (fundamental) and speculative (non-fundamental) oil demand shocks to the real oil price $(O P)$, the latter disturbances being captured by the Working's-T index $(W T)$ and the futures basis shocks $(F B)$. Finally, real non-energy commodities price index returns, real stock market returns, and real gold price returns follow in the ordering. This allows for measuring the contemporaneous spillover of oil price shocks to non-energy commodities markets and the stock market, as well as studying the interaction across various classes of assets under a portfolio allocation perspective. The ordering is also motivated by letting stock market returns embed all contemporaneous information on macro-financial and oil market conditions and gold (being a "crisis asset" whose demand is expected to be stronger during periods of economic and financial turmoil) also be affected by stock market dynamics.

Finally, as a general caveat, it should be recalled that the interpretation of the results of the forecast error variance and historical decompositions presented in the following section in terms of structural economic and financial disturbances may be sensitive to the chosen ordering of the variables. As the 
implied recursive structural model is exactly identified, the assumed restrictions cannot be tested. Yet, as a robustness check, pairwise weak exogeneity testing can always be carried out. A joint test, based on the Bonferroni bounds principle, carried out using the 528 possible bivariate tests, implied by the recursive structure, which can be computed out of the 33 variables, would not reject, even at the $20 \%$ significance level, the weak exogeneity null hypothesis.

\section{Empirical results}

Based on the identification scheme discussed in the previous section, concerning oil market demand and supply interactions, eight structural shocks are then identified, i.e. an oil reserves shock, net positive and negative production shocks, a refinery margins shock, oil consumption and inventories preferences shocks, and other real oil price and nominal oil price volatility shocks.

Moreover, eight structural macroeconomic shocks can be identified, i.e., an aggregate demand shock, a labor supply shock, a (negative) labor demand shock, a productivity shock, US fiscal and trade deficit shocks, a (global) fiscal stance shock, and a core inflation shock.

Finally, seventeen financial structural shocks are identified, i.e., an excess liquidity shock; a set of speculative asset price (portfolio) shocks, i.e., a real stock market prices shock, a real housing prices shock, a real gold price shock and a real non energy commodity price index shock; an US\$ exchange rate index shock; a risk-free rate shock; two oil futures market speculative shocks, i.e., Working's-T and futures basis shocks; a set of risk factors shocks, measuring revisions in market expectations about future fundamentals, i.e., a risk aversion shock, size, value, leverage, stocks' liquidity, and momentum factor shocks; a term spread shock; a residual economic and financial fragility index shock. Details on the interpretation of the structural shocks are provided in the Appendix.

We then proceed to the assessment of the relative importance of the various sources of structural disturbances in determining the behavior of the US financial fragility index. To this purpose, first a forecast error variance decomposition is performed over various horizons; second, focusing on several important episodes of financial and economic distress, the changes in the index are decomposed into portions attributable to structural shocks of different nature. 


\subsection{Forecast error variance decomposition}

Median forecast error variance decompositions have been computed up to a horizon of ten years (40 quarters). Table 1 shows the results for selected horizons, that we denote, for expository purposes, as "very short-term" (2 quarters), "short-term" (between 1 and 2 years), "medium-term" (between 3 and 5 years), and "long-term" (10 years) horizons. ${ }^{7}$ Panel A of the table shows the contribution (in percentage points) of each individual structural shock to the forecast error variance of the US fragility index at the various horizons. For ease of discussion, Panel B presents the results with reference to general categories of disturbances, distinguishing among oil market supply side shocks ( $S U P$, including shocks to oil reserves, net negative and positive production, and refinery margins), shocks to oil demand ( $D E M$, including disturbances to oil consumption and inventories preferences), a group of macroeconomic disturbances ( $M A C$, including labor demand and supply, aggregate demand, the fiscal stance, the US budget and trade deficits, core inflation and productivity), a group of fundamental financial shocks (FIN, comprising excess liquidity, the risk-free rate, the term spread, housing prices, risk aversion, size, value, momentum, stocks' liquidity and leverage factors, real non-energy commodity prices, real stock prices, real gold prices, real oil price and nominal oil price volatility), US\$ exchange rate disturbances $(X)$, and speculative/non fundamental financial shocks $(S P C$, including the Working's-T index, and the oil futures basis). Finally, Panel B presents the results for sub-categories of macroeconomic and financial shocks, namely labor market shocks ( $L M$ : labor demand and supply), aggregate demand disturbances $(Y)$, core inflation shocks $(N)$, productivity disturbances $(W)$, deficits shocks (FT: fiscal stance, US fiscal and trade deficits), liquidity and interest rate shocks ( $M P$ : excess liquidity, risk-free rate, term spread), portfolio allocation shocks $(P A$ : real housing prices, real non-energy commodity prices, real stock prices, real gold price, real oil price) and risk factors disturbances ( $R F$ : nominal oil price volatility, risk aversion, size, value, momentum, stocks' liquidity and leverage factors).

As shown in the last column of Table 1, the US fragility index is strongly endogenous, since its own shock only accounts for about $15 \%$ of total fluctuations in the very short-term and about $11 \%$ in the medium- to long-term. This finding supports the proposed interpretation of the fragility index as a synthetic measure, conveying multiple information on different factors determining the state of the financial system. Three main categories of structural shocks account for the bulk of fluctuations in the US financial fragility index. First, fundamental financial shocks $(F I N)$ yield the largest contri-

\footnotetext{
${ }^{7} \mathrm{~A}$ full set of results is available upon request from the authors.
} 
bution: $50 \%$ in the short-term and $40 \%$ in the long-term. Within this category, risk factors shocks $(R F)$ are particularly relevant $(34 \%$ in the very short-term and $27 \%$ in the long-term), mainly due in the very short-term to risk aversion disturbances $(16 \%)$ and value factor shocks $(14 \%)$, and to the size and value factor disturbances over the long-term horizon $(10 \%$ and $8 \%$ respectively). Portfolio allocation shocks $(P A)$ follow, accounting for $13 \%$ of fragility index fluctuations over the short-term horizon and $10 \%$ in the long-term. Second, macroeconomic disturbances $(M A C)$ yield a sizable contribution to fragility index fluctuations, accounting for about $25 \%$ of the index variability in the very short-term, and still $15 \%$ over the longer 10 -year horizon. Among macroeconomic shocks, aggregate demand (real activity) $(8 \%)$, deficits $(8 \%)$ and labor productivity $(6 \%)$ shocks are particularly important sources of fluctuations in the short-term, their relevance declining as the forecast horizon increases. Finally, oil market supply side disturbances $(S U P)$ sizeably contribute to fragility index fluctuations in the medium- to long-term (20\% to $25 \%$ ), negative net oil production shocks being the most relevant shock (20\%). All other sources of structural disturbances play a more limited role in accounting for fluctuations in the fragility index at any forecasting horizon.

\subsection{Historical decomposition}

In Table 2 and Figures 2-4, changes in the level of the US financial fragility index (net of base prediction) over relevant sub-periods and specific episodes are decomposed into portions attributable to macroeconomic and financial structural disturbances. In particular, two sub-periods are considered: 1986(4) through 2006(4), roughly corresponding to the "Great Moderation" period, preceding the 2007 financial crisis, and 2007(1) through 2010(3), covering the financial crisis and the ensuing recession. In Table 2, we also report details concerning few episodes of interest in the sample, including the 1987(4)stock market crash, the 1990(4) first Persian Gulf War and associated oil price shock, the 1998(4) East Asia crisis, the 2000(2) burst of the dot-com bubble, and the 2007-2009 financial crisis. All episodes mentioned above (and highlighted in Figure 1 by means of vertical lines and shaded areas) are characterized by a quarterly increase of over 20 b.p. in the fragility index. As for the forecast error variance decomposition, the discussion will focus on various categories of shocks, rather than on individual structural disturbances. 


\subsubsection{The Great Moderation period}

As shown in Figure 2, over the whole 1986-2006 period, macroeconomic $(M A C)$, financial $(F I N)$ and oil market supply side $(S U P)$ disturbances have been the largest contributors to US fragility index dynamics. In particular, with the only exception of 1990(4), all the specific episodes selected in Table 2 share some common features, being largely determined by financial shocks, which account almost entirely ( $80 \%$ to $95 \%$ ) for the overall increase in the fragility index (ranging from 27 to 36 b.p.). In particular, risk factor shocks are always dominant (their contribution going from 16 to 23 b.p.), with portfolio disturbances also playing a role in 2000(2), and liquidity and interest rate shocks in 1987(4). Apart from the 2000(2) episode, macroeconomic disturbances have had a stabilizing effect, dampening to some extent the increase of the fragility index (ranging from -5 to -8 b.p.). Differently, the 1990(4) episode, featuring an increase in the index by 28 b.p., can be fully attributed to disturbances coming from the oil market, with oil supply, demand and speculative shocks contributing importantly (by 16, 7 and 6 b.p, respectively); also in this case, macroeconomic (and exchange rate) shocks have partially offset the increase in the fragility index (-5 b.p.).

\subsubsection{The 2007-2010 crisis period}

Over the 2007-2010 period, sizable increases in the fragility index, strictly related to relevant financial and economic events, are observed. For instance, the 22 b.p. and 21 b.p. increases in 2007(3) and 2007(4) can be associated with the beginning of the financial crisis in August 2007 and its aftermath, while the 27 b.p. and 102 b.p. increases in 2008(3) and 2008(4) signal the deepening of the financial crisis. Then, five remarkable contractions in the fragility index can be noted over the period 2009(1) through 2010(1), as economic and financial conditions progressively, though temporarily, improved.

As shown in Table 2 and in Figures 3 and 4, the behavior of the fragility index in the second half of 2007 is largely accounted for by financial shocks (14 b.p. and 8 b.p. respectively in 2007(3) and 2007(4)), with shocks coming from the oil market (related to both the demand and the supply side and to financial speculation) also providing a sizable contribution (12 and 8 b.p. in the two quarters). Differently, changes in the fragility index occurred in 2008(3) and 2008(4) are largely driven by macroeconomic shocks. In 2008(3) the overall 27 b.p. increase in the index is fully determined by macroeconomic disturbances, i.e., deficit and productivity shocks, accounting for $70 \%$ of the index increase; also, macroeconomic shocks account for $50 \%$ of the 49 b.p. increase in the index observed in 2008(4), with a sizeable contribution from 
all sources of macroeconomic disturbances, apart from expected inflation. Also financial shocks (especially attributable to portfolio allocation and risk factors) played a relevant role in the final quarter of 2008, determining an increase in the fragility index of 35 b.p. Overall, macroeconomic and financial disturbances jointly account for about $85 \%$ of the 102 b.p. increase in the fragility index in 2008(4), oil market shocks adding an additional 13 b.p. increase.

On the other hand, the 2009(1) through 2010(1) period displays progressively improving economic and financial conditions, with the fragility index falling by over 200 b.p. cumulatively, more than compensating the 2007(3)2008(4) 170 b.p. increase. This episode is again largely driven by the identified macroeconomic and financial disturbances, which jointly account for $70 \%$ to $90 \%$ of the index contraction in 2009(1)-2009(3), 50\% in 2009(4). Apart from core inflation, all macroeconomic shocks yield a sizable contribution to fragility index downward dynamics over the investigated sub period; a similar conclusion holds for financial shocks, with risk factors shocks dominating in 2009(1) and 2009(3).

In order to gauge the effects of the macroeconomic and financial shocks on the level of the fragility index, in Figure 5 the cumulative historical decomposition, with reference to various categories of shocks, is plotted. As shown in Figure 5, over the whole period investigated, fundamental financial shocks were the major upward driver of the fragility index, while oil market supply side shocks were stabilizing up to the mid 1990s and destabilizing thereafter. Moreover, macroeconomic shocks had, in general, a stabilizing impact, reinforcing the destabilizing effects of financial disturbances only during the subprime financial crisis and Great Recession episodes. Moreover, when the joint contribution of macroeconomic and financial shocks (the latter including non fundamental financial and exchange rate disturbances) is considered, there is evidence that macroeconomic shocks were dominating over financial disturbances up to the mid 1990s, and then sufficiently strong to offset the latter thereafter, until the occurrence of subprime crisis. Then, our results support the view that sees the recent financial crisis as marking the end of the Great Moderation period. 


\section{Conclusions}

The recent financial crisis has highlighted the fragility of the US (and other countries') financial system under several respects. A number of indicators and financial variables are closely observed and used as signals of financial market distress. In this paper, a summary index of financial fragility is obtained by combining information conveyed by the "Agency", "Ted" and "BAA-AAA" spreads, timely capturing changes in credit and liquidity risk, distress in the mortgage market, and corporate default risk, all important elements to evaluate the solidity of the financial system. We investigate the determinants of fluctuations in the proposed index of US financial fragility over the 1986-2010 period by means of a large-scale factor vector autoregressive model which allows us to consider a broad range of global (worldwide) and domestic (US) macroeconomic and financial driving forces.

The empirical analysis shows that observed fluctuations in the financial fragility index can be attributed to identified (global and domestic) macroeconomic, financial and oil-market structural disturbances, over both shortand long-term (10-year) horizons. Fundamental financial shocks yield the largest contribution, accounting for $40 \%-50 \%$ of the index variability, whereas macroeconomic disturbances explain about $20 \%$ of fluctuations in the index, and oil market supply side shocks disturbances account for an additional $25 \%$ over the long-term horizon (though explaining only $5 \%$ in the short-term). Moreover, the historical decomposition of the changes in the index during specific episodes, including the financial market crashes occurred in 1987, 1998 and 2000, and the more recent period of financial turmoil and general economic recession (2007-2009), show that sizable fluctuations in the index are largely determined by fundamental financial shocks (related to risk factors shocks in particular), while macroeconomic disturbances have generally had a stabilizing effect. Actually, consistent with the Great Moderation phenomenon, macroeconomic shocks had a stabilizing impact on the fragility index until the occurrence of the recent financial crisis, dominating over financial shocks until the mid 1990s, and offsetting the latter thereafter. Overall, the results support our proposed macroeconomic-financial-oil market framework in modelling the determinant driving forces of US financial fragility. 


\section{References}

[1] Adrian T., E. Etula and T. Muir, 2011, Financial intermediaries and the cross-section of asset returns, Federal Reserve Bank of New York Staff Reports n. 464.

[2] Bagliano, F.C. and C. Morana, 2012, The Great Recession: US dynamics and spillovers to the world economy, Journal of Banking and Finance, 36, $1,1-13$.

[3] Carhart, M., 1997, On persistence of mutual fund performance, Journal of Finance, 52, 57-82.

[4] Fama, E.F. and K.R. French, 1993, Common risk factors in the returns on stocks and bonds, Journal of Financial Econonomics, 33, 3-56.

[5] Granger C.W. and Y. Jeon, 2004, Thick modelling, Economic Modelling, $21,323-343$.

[6] Morana, C., 2011, Factor vector autoregressive estimation of heteroskedastic persistent and non persistent processes subject to structural breaks, available at SSRN: http://ssrn.com/abstract $=1756376$.

[7] Morana, C., 2012, PC-VAR estimation of vector autoregressive models, Open Journal of Statistics, 2, 251-259.

[8] Pastor L. and R.F. Stambaugh, 2003, Liquidity risk and expected stock returns, Journal of Political Economy, 111, 3, 642-685.

[9] Working H., 1960, Speculation on hedging markets, Stanford University Food Research Institute Studies 1, 185-220. 


\section{Appendix: Interpretation of structural shocks}

In the empirical model, three sets of structural disturbances are identified: a set of oil market shocks, a set of macroeconomic disturbances, and a large variety of shocks of a financial nature.

\section{Oil market shocks}

In the empirical model, eight identified structural shocks drive the dynamics of the oil market, namely an oil reserves shock, net positive and negative production shocks, a refinery margins shock, oil consumption and inventories preferences shocks, and other real oil price and nominal oil price volatility shocks. The interpretation of the own shocks in terms of reserves, net production and refinery margins shocks is clear-cut, the latter accounting for about $100 \%$ of each variable fluctuations on impact (not reported). The interpretation of the oil consumption and inventories own shocks in terms of preferences shocks depends on the former being net of the contemporaneous effect of the macroeconomic variables driving flow oil demand, and the latter also of the effect of the (financial) variables driving financial oil demand. Similarly for the real oil price and nominal oil price volatility own shocks, to which we do not attach an economic interpretation and simply refer as other real oil price and nominal oil price volatility shocks.

\section{Macroeconomic shocks}

The set of macroeconomic shocks includes eight structural disturbances identified as an aggregate demand shock, a labor supply shock, a (negative) labor demand shock, a productivity shock, US fiscal and trade deficit shocks, a (global) fiscal stance shock, and a core inflation shock.

The aggregate demand (real activity) shock accounts for $80 \%$ of real activity fluctuations in the very short-term, also showing a positive impact on real activity ( $0.67 \%$ within two quarters and $0.29 \%$ in the long-term) and the nominal factor $(0.02 \%$, long-term). The labor supply shocks accounts for $90 \%$ of employment fluctuations in the very short-term, sizably contributing to real activity fluctuations in the short-to medium-term (up to 20\%). The shock has a positive effect on employment $(0.24 \%$ in the very short-term; $1.3 \%$ in the long-term) and real activity (0.64\% in the short-term; $0.18 \%$ in the medium-term), as well as a negative effect on the unemployment rate $(-0.92 \%$ in the short-term; $-0.58 \%$ in the long term) and the real wage $(-0.7 \%$ in the short-term; $-1.3 \%$ in the long-term). The (negative) labor demand 
shock accounts for $90 \%$ of unemployment rate fluctuations in the very shortterm, with a positive effect on the unemployment rate $(0.28 \%$ in the very short-term; $0.35 \%$ in the long-term) and a negative effect employment ($0.10 \%$ short-term), real activity $(-0.07 \%$ in the very short-term; $-0.17 \%$ in the long-term), and the real wage $(-0.09 \%$ in the short-term; $-0.33 \%$ in the long-term).

The productivity shock is the largest contributor to real activity longterm fluctuations (20\%), stimulating real activity at any horizon $(0.3 \%$ at the 1-year horizon and $0.7 \%$ at the 10 -year horizon) and having a negative shortterm impact on the nominal factor $(-0.01 \%)$. It also positively impacts on the real short-term rate at any horizon $(0.11 \%$ in the long-term). The US fiscal deficit shock accounts for $85 \%$ of US fiscal deficit to GDP ratio fluctuations in the very short-term. It leads to a long-term contraction in employment $(-0.37 \%)$, a short-term contraction in real activity $(-0.23 \%)$ and a temporary increase in the unemployment rate $(0.25 \%)$. The US trade deficit shock accounts for $80 \%$ of US trade deficit to GDP ratio fluctuations in the very short-term. It leads to a long-term contraction in real activity $(-0.4 \%)$ and a long-term increase in the unemployment rate $(0.3 \%)$. The above dynamics are consistent with both shocks (being net of the global aggregate demand, labor demand and supply, and fiscal stance shocks) signaling growing longterm global imbalances.

The fiscal stance shock accounts for $58 \%$ of public expenditure to GDP ratio fluctuations in the very short-term. It leads to a permanent contraction in employment $(-0.84 \%)$, real activity $(-0.5 \%)$ and to a permanent increase in the unemployment rate $(0.73 \%)$. By being net of the shocks accounting for the state of the global business cycle (aggregate demand, labor demand and supply shocks), it is related to excess public expenditure dynamics. Finally, the core inflation shock accounts for $60 \%$ of nominal factor fluctuations in the very short-term, with a negative impact on employment $(-0.3 \%$, longterm) and real activity $(-0.24 \%$, short-term), and a positive effect on the unemployment rate $(0.19 \%$, short-term) and real wages $(0.4 \%$, long-term); it also triggers a permanent increase in the real interest rate $(0.05 \%)$.

\section{Financial shocks}

On the financial side, seventeen structural shocks are identified, namely an excess liquidity shock, a set of speculative asset price (portfolio) shocks (i.e. a real stock market prices shock, a real housing prices shock, a real gold price shock and a real non energy commodity price index shock), an US\$ exchange rate index shock, a risk-free rate shock, two oil futures market speculative shocks (i.e. Working's-T and futures basis shocks), a set of risk factors 
shocks measuring revisions in market expectations about future fundamentals (i.e. a risk aversion shock, size, value, leverage, stocks' liquidity, and momentum factor shocks), a term spread shock, and a residual economic and financial fragility index shock.

The excess liquidity shock accounts for $35 \%$ of excess liquidity fluctuations in the very short-term and leads to a permanent contraction in the real short-term interest rate $(-0.07 \%)$, as well as in the real long-term interest rate $(-0.03 \%$, implied by the $0.04 \%$ increase in the term spread following the shock). Being contemporaneously orthogonal to macroeconomic, liquidity and interest rates shocks, the own real stock market, housing, gold, and non energy commodity price disturbances bear the interpretation of speculative asset price (portfolio) shocks; the latter account for 21\%, 68\%, $24 \%$ and $38 \%$ of real stock market, housing, non energy commodities index and gold price fluctuations in the very short-term, respectively. The US\$ exchange rate index shock accounts for $50 \%$ of the US\$ exchange rate index fluctuations in the very short-term. Due to the ordering, it is contemporaneously orthogonal to macroeconomic and liquidity/interest rate shocks, bearing therefore the interpreatation of a purely financial shock. The risk-free rate shock accounts for $30 \%$ of short-term real interest rate fluctuations in the very short-term. Being net of the contemporaneous effect of macroeconomic and liquidity shocks, it may be interpreted in terms of a short-term bonds risk premium shock.

The oil futures market speculative shocks (i.e. the Working's-T and futures basis shocks) account for 55\% (each) of Working's-T and futures basis fluctuations in the very short-term, respectively. Their interpretation in terms of oil futures market speculative shocks follows from their positive impact on both the oil futures and spot price, also affecting inventories at various horizons, in addition to being orthogonal to the set of macroeconomic and financial shocks driving flow and fundamental financial oil demand. Being contemporaneously orthogonal to macroeconomic, liquidity and interest rates shocks, the risk factors shocks measure revisions in market expectations about future fundamentals. The risk aversion, size, value, leverage, stocks' liquidity, and momentum factor shocks account for $60 \%, 54 \%, 56 \%, 35 \%$, $51 \%$ and $54 \%$ of stock market volatility, size, value, momentum, stocks' liquidity and leverage factors fluctuations, respectively, in the very short-term. The term spread shock accounts for $64 \%$ of term spread fluctuations in the very short-term.

Finally, the economic and financial fragility index shock accounts for $15 \%$ of the economic and financial fragility index fluctuations in the very shortterm. By being orthogonal to all the other disturbances considered in the model, it is interpreted as a residual fragility shock. 


\begin{tabular}{|c|c|c|c|c|c|c|c|c|c|c|c|c|c|c|c|c|c|c|c|c|c|c|c|c|c|c|c|c|c|c|c|c|c|}
\hline \multicolumn{34}{|c|}{ Panel A: contribution of individual structural shocks } \\
\hline & $\mathbf{R}$ & $\mathrm{Pm}$ & Pp & RM & $E$ & $\mathbf{U}$ & $\mathbf{Y}$ & G & Fd & $\mathrm{Td}$ & $\mathbf{N}$ & $\mathbf{w}$ & C & $\mathrm{L}$ & SR & TS & $\mathrm{H}$ & $\mathrm{x}$ & FV & SMB & HML & MOM & PSL & LEV & WT & FB & INV & OP & OV & M & $\mathbf{F}$ & GD & FRA \\
\hline 0 & 4.4 & 0.2 & 0.0 & 0.0 & 4.6 & 0.0 & 8.0 & 0.1 & 3.2 & 1.4 & 1.2 & 6.1 & 1.6 & 0.0 & 0.2 & 0.2 & 1.6 & 0.8 & 15.8 & 0.1 & 13.9 & 1.5 & 0.0 & 0.0 & 0.1 & 5.0 & 0.9 & 0.1 & 2.7 & 10.6 & 0.2 & 0.6 & 15.0 \\
\hline 2 & 3.6 & 0.7 & 0.5 & 1.7 & 5.7 & 1.4 & 5.4 & 0.9 & 4.0 & 0.9 & 0.8 & 2.4 & 3.7 & 0.2 & 3.4 & 0.2 & 1.1 & 0.4 & 6.4 & 0.5 & 16.2 & 2.3 & 2.2 & 0.3 & 0.1 & 5.3 & 0.5 & 0.9 & 4.8 & 9.7 & 0.1 & 1.1 & 12.7 \\
\hline 4 & 3.1 & 1.9 & 0.5 & 1.3 & 4.9 & 1.1 & 5.2 & 0.8 & 4.0 & 1.7 & 0.8 & 3.2 & 3.8 & 1.5 & 5.0 & 0.3 & 1.7 & 0.7 & 4.8 & 0.5 & 15.7 & 1.9 & 3.2 & 0.3 & 0.1 & 4.1 & 0.8 & 0.8 & 3.7 & 7.9 & 0.3 & 0.8 & 13.5 \\
\hline 6 & 3.2 & 5.3 & 0.4 & 1.1 & 6.0 & 1.0 & 4.1 & 1.9 & 4.9 & 1.3 & 0.6 & 3.4 & 3.1 & 1.8 & 3.7 & 0.4 & 2.9 & 0.6 & 4.2 & 4.0 & 12.8 & 1.3 & 4.2 & 0.3 & 0.1 & 2.9 & 1.4 & 0.6 & 3.0 & 6.0 & 0.9 & 0.6 & 12.2 \\
\hline 8 & 2.5 & 9.6 & 0.5 & 0.8 & 6.3 & 1.1 & 2.9 & 2.7 & 4.2 & 1.2 & 0.5 & 2.5 & 3.0 & 1.3 & 2.6 & 0.6 & 3.9 & 0.7 & 3.1 & 7.3 & 11.1 & 1.0 & 4.3 & 0.4 & 0.2 & 2.4 & 1.8 & 0.5 & 3.0 & 5.4 & 1.2 & 0.4 & 11.2 \\
\hline 12 & 1.9 & 13.1 & 1.4 & 0.9 & 6.2 & 1.1 & 2.1 & 3.8 & 3.5 & 0.9 & 0.5 & 1.7 & 3.0 & 1.2 & 1.8 & 0.8 & 4.3 & 0.9 & 2.1 & 8.8 & 9.2 & 0.7 & 4.1 & 0.5 & 0.3 & 1.9 & 2.3 & 0.4 & 3.0 & 5.0 & 1.3 & 0.3 & 11.0 \\
\hline 20 & 2.0 & 16.4 & 1.6 & 0.9 & 5.2 & 1.2 & 1.4 & 3.9 & 2.9 & 0.6 & 0.4 & 1.4 & 3.4 & 1.0 & 1.3 & 1.0 & 4.1 & 1.0 & 1.4 & 9.8 & 8.5 & 0.5 & 4.3 & 0.5 & 0.3 & 1.5 & 2.6 & 0.3 & 2.9 & 4.9 & 1.3 & 0.2 & 11.2 \\
\hline 40 & 2.2 & 20.2 & 1.8 & 0.7 & 4.5 & 1.3 & 0.8 & 3.3 & 2.8 & 0.3 & 0.2 & 1.5 & 4.1 & 1.0 & 0.9 & 0.9 & 3.8 & 0.7 & 0.8 & 9.9 & 8.4 & 0.3 & 4.6 & 0.4 & 0.3 & 1.3 & 2.5 & 0.3 & 2.9 & 4.6 & 1.3 & 0.1 & 11.1 \\
\hline \multicolumn{17}{|c|}{ Panel B: contribution of categories of shocks } & & & & & & & & & & & & & & & & & \\
\hline
\end{tabular}

\begin{tabular}{|c|r|r|c|c|c|c|c|c|c|c|c|c|c|c|c|}
\hline \multicolumn{10}{|c|}{ Panel B: contribution of categories of shocks } & \multicolumn{10}{|c|}{ MAC } & \multicolumn{10}{|c|}{ FIN } \\
\hline & SUP & DEM & MAC & X & FIN & SPC & FRA & LM & Y & FT & N & W & MP & PA & RF \\
\hline $\mathbf{0}$ & 4.6 & 2.5 & 24.5 & 0.8 & 47.4 & 5.1 & 15.0 & 4.7 & 8.0 & 8.1 & 1.2 & 6.1 & 0.4 & 13.0 & 34.0 \\
\hline $\mathbf{2}$ & 6.5 & 4.2 & 21.4 & 0.4 & 49.4 & 5.4 & 12.7 & 7.1 & 5.4 & 6.3 & 0.8 & 2.4 & 3.7 & 12.9 & 32.8 \\
\hline $\mathbf{4}$ & 6.9 & 4.6 & 21.7 & 0.7 & 48.4 & 4.2 & 13.5 & 6.0 & 5.2 & 6.0 & 0.8 & 3.2 & 6.8 & 11.5 & 30.1 \\
\hline $\mathbf{6}$ & 9.9 & 4.5 & 23.2 & 0.6 & 46.7 & 3.0 & 12.2 & 7.0 & 4.1 & 6.0 & 0.6 & 3.4 & 5.9 & 10.9 & 29.8 \\
\hline $\mathbf{8}$ & 13.4 & 4.8 & 21.4 & 0.7 & 46.0 & 2.6 & 11.2 & 7.3 & 2.9 & 5.7 & 0.5 & 2.5 & 4.6 & 11.3 & 30.1 \\
\hline $\mathbf{1 2}$ & 17.4 & 5.3 & 19.7 & 0.9 & 43.5 & 2.1 & 11.0 & 7.3 & 2.1 & 5.9 & 0.5 & 1.7 & 3.8 & 11.3 & 28.5 \\
\hline $\mathbf{2 0}$ & 20.8 & 6.1 & 17.1 & 1.0 & 42.0 & 1.9 & 11.2 & 6.4 & 1.4 & 5.3 & 0.4 & 1.4 & 3.3 & 10.8 & 27.9 \\
\hline $\mathbf{4 0}$ & 24.9 & 6.6 & 14.8 & 0.7 & 40.2 & 1.6 & 11.1 & 5.8 & 0.8 & 4.1 & 0.2 & 1.5 & 2.8 & 10.2 & 27.2 \\
\hline
\end{tabular}

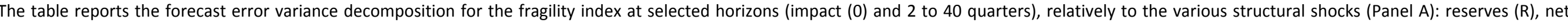

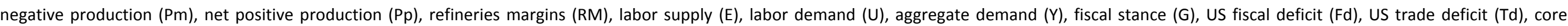

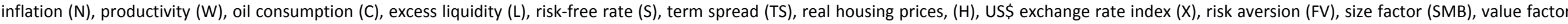

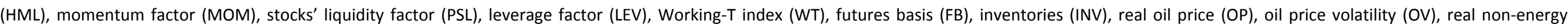

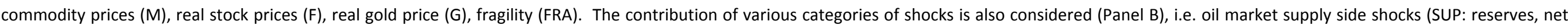

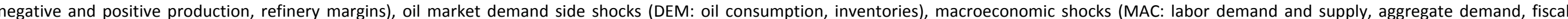

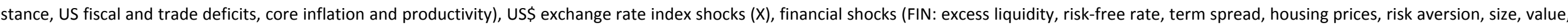

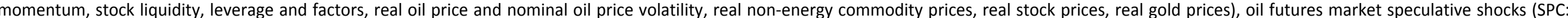

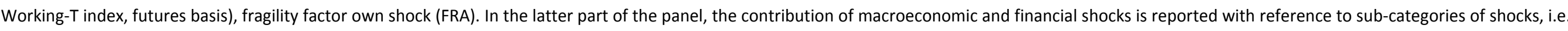

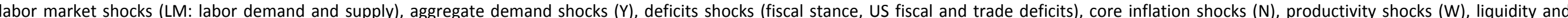

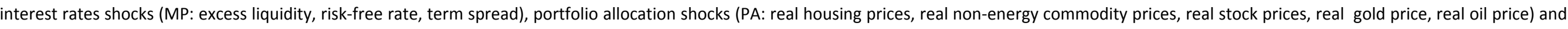
risk factors shocks (RF: nominal oil price volatility, risk aversion, size, value, momentum, stocks' liquidity and leverage factors). 
Table 2: Historical decomposition of the US financial fragility index: contribution of various categories of shocks in selected episodes

\begin{tabular}{|c|c|c|c|c|c|c|c|c|c|c|c|c|c|c|c|c|c|}
\hline & \multicolumn{9}{|c|}{ Panel A: categories of shocks } & \multicolumn{8}{|c|}{ Panel B: sub categories of macroeconomic and financial shocks } \\
\hline & SUP & DEM & MAC & $\mathrm{X}$ & FIN & SPC & OWN & MF & ACT & LM & $\mathbf{Y}$ & $\mathbf{F T}$ & $\mathbf{N}$ & $\mathbf{w}$ & MP & PA & RF \\
\hline $87(4)$ & 0.04 & 0.01 & -0.05 & -0.02 & 0.30 & 0.07 & 0.02 & 0.25 & 0.36 & -0.03 & -0.03 & 0.02 & -0.01 & 0.00 & 0.05 & 0.01 & 0.24 \\
\hline $90(4)$ & 0.16 & 0.07 & -0.02 & -0.03 & 0.01 & 0.06 & 0.03 & -0.01 & 0.28 & 0.05 & 0.03 & -0.08 & -0.03 & 0.00 & 0.02 & 0.03 & -0.04 \\
\hline 98(4) & 0.02 & -0.02 & -0.08 & 0.00 & 0.26 & 0.01 & 0.09 & 0.18 & 0.27 & -0.04 & -0.13 & 0.07 & -0.01 & 0.03 & 0.03 & 0.01 & 0.23 \\
\hline $00(2)$ & 0.01 & -0.01 & 0.03 & -0.01 & 0.25 & 0.00 & 0.04 & 0.28 & 0.31 & -0.02 & 0.06 & -0.10 & 0.00 & 0.09 & 0.01 & 0.08 & 0.16 \\
\hline & & & & & & & & & & & & & & & & & \\
\hline $07(3)$ & 0.07 & -0.01 & -0.04 & 0.04 & 0.14 & 0.06 & -0.03 & 0.09 & 0.22 & 0.02 & 0.00 & 0.02 & -0.02 & -0.06 & -0.06 & 0.07 & 0.13 \\
\hline $07(4)$ & 0.07 & 0.00 & 0.03 & 0.00 & 0.08 & 0.01 & 0.01 & 0.12 & 0.21 & 0.04 & -0.05 & 0.05 & 0.00 & -0.02 & 0.04 & 0.00 & 0.04 \\
\hline 08(1) & -0.02 & -0.02 & 0.08 & 0.02 & -0.06 & -0.04 & -0.01 & 0.02 & -0.04 & -0.01 & 0.01 & 0.04 & -0.03 & 0.06 & 0.07 & -0.17 & 0.04 \\
\hline $08(2)$ & -0.03 & -0.01 & -0.02 & -0.01 & 0.11 & -0.02 & 0.01 & 0.08 & 0.03 & -0.01 & 0.03 & -0.09 & 0.02 & 0.03 & 0.11 & -0.06 & 0.06 \\
\hline 08(3) & 0.04 & 0.00 & 0.28 & 0.01 & 0.00 & -0.02 & -0.03 & 0.28 & 0.27 & 0.03 & 0.03 & 0.10 & 0.02 & 0.10 & 0.01 & 0.05 & -0.06 \\
\hline $08(4)$ & 0.03 & 0.06 & 0.49 & 0.03 & 0.35 & 0.04 & 0.03 & 0.84 & 1.02 & 0.16 & 0.08 & 0.14 & 0.01 & 0.10 & 0.02 & 0.10 & 0.24 \\
\hline 09(1) & -0.03 & -0.04 & -0.09 & -0.04 & -0.37 & -0.01 & -0.05 & -0.47 & -0.64 & -0.03 & 0.01 & -0.05 & 0.01 & -0.02 & -0.05 & -0.09 & -0.23 \\
\hline $09(2)$ & -0.08 & -0.02 & -0.22 & -0.04 & -0.15 & -0.02 & -0.01 & -0.37 & -0.53 & -0.04 & -0.08 & -0.09 & 0.03 & -0.04 & -0.12 & -0.02 & -0.01 \\
\hline 09(3) & -0.02 & -0.01 & -0.33 & -0.02 & -0.19 & 0.01 & -0.01 & -0.52 & -0.57 & -0.16 & -0.04 & -0.06 & 0.01 & -0.08 & 0.03 & -0.06 & -0.17 \\
\hline 09(4) & -0.05 & 0.02 & -0.17 & -0.03 & 0.07 & -0.03 & -0.01 & -0.10 & -0.19 & -0.08 & -0.01 & -0.04 & -0.01 & -0.03 & -0.01 & 0.04 & 0.04 \\
\hline $10(1)$ & 0.01 & 0.01 & -0.13 & 0.04 & -0.07 & 0.01 & 0.00 & -0.19 & -0.13 & -0.09 & 0.03 & -0.06 & -0.01 & 0.00 & 0.03 & -0.02 & -0.07 \\
\hline 10(2) & 0.07 & -0.06 & 0.12 & -0.01 & 0.08 & -0.02 & -0.01 & 0.19 & 0.16 & -0.01 & 0.05 & 0.10 & 0.03 & -0.07 & 0.04 & -0.02 & 0.06 \\
\hline 10(3) & 0.02 & -0.01 & 0.14 & 0.00 & -0.14 & -0.04 & 0.08 & -0.01 & 0.03 & 0.04 & 0.02 & 0.04 & -0.01 & 0.05 & 0.02 & -0.04 & -0.12 \\
\hline
\end{tabular}

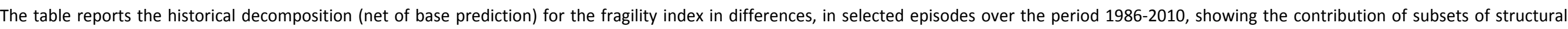

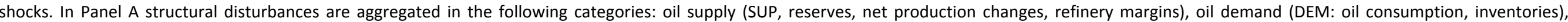

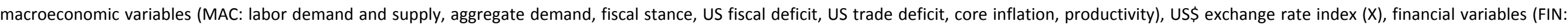

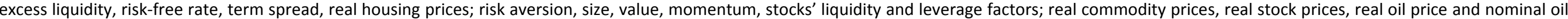

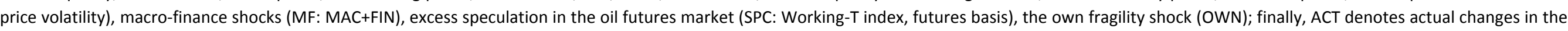

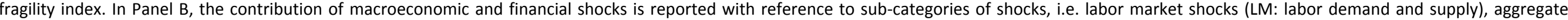

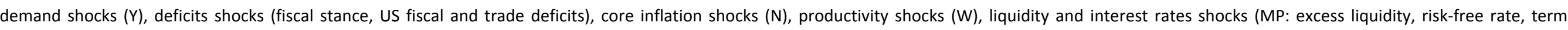

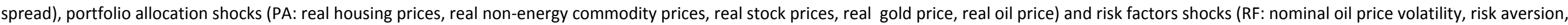
size, value, momentum, stocks' liquidity and leverage factors). 


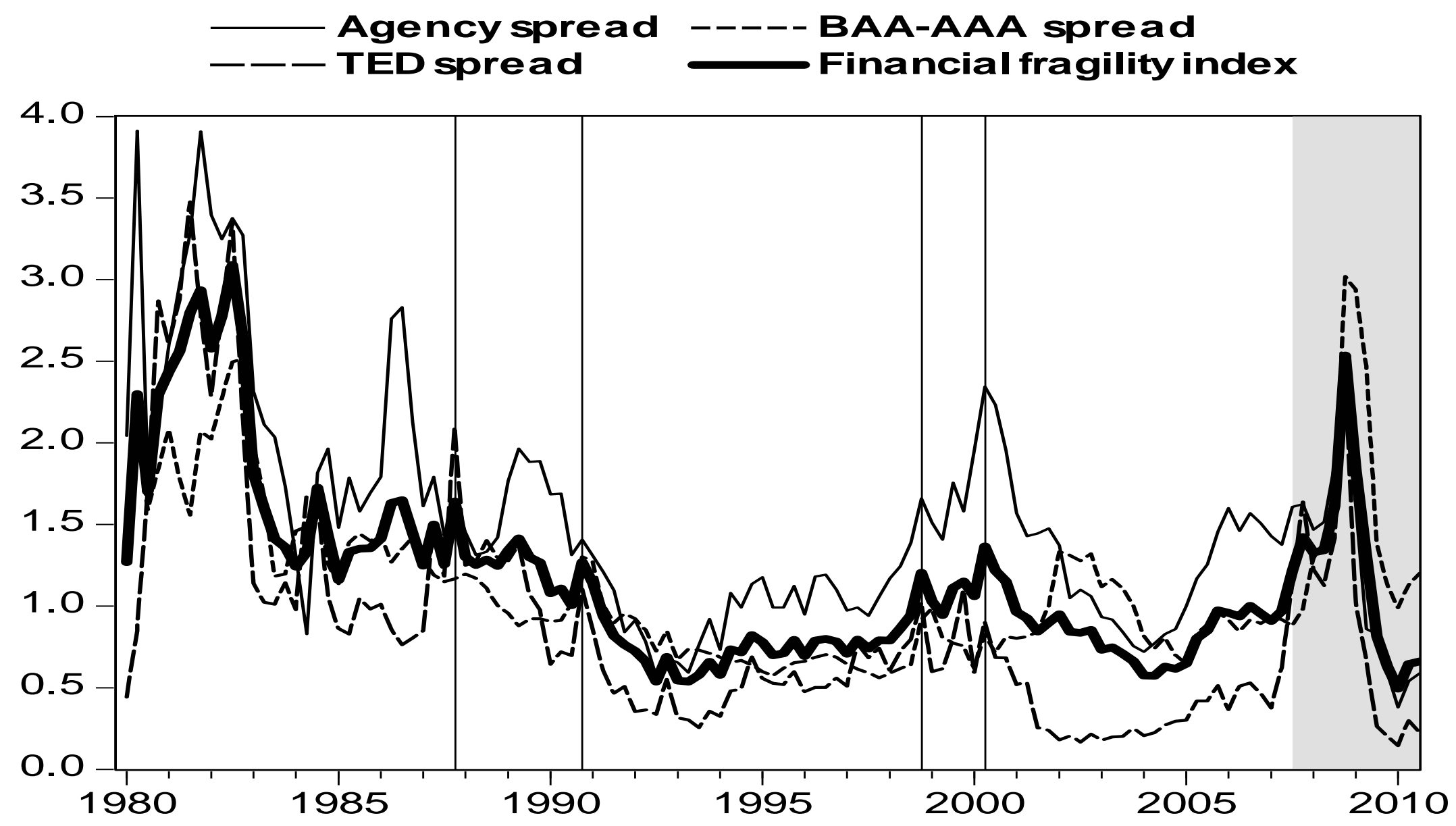

Figure 1: The AGENCY, TED and BAA-AAA spread, and the US financial fragility index (1980-2010). 

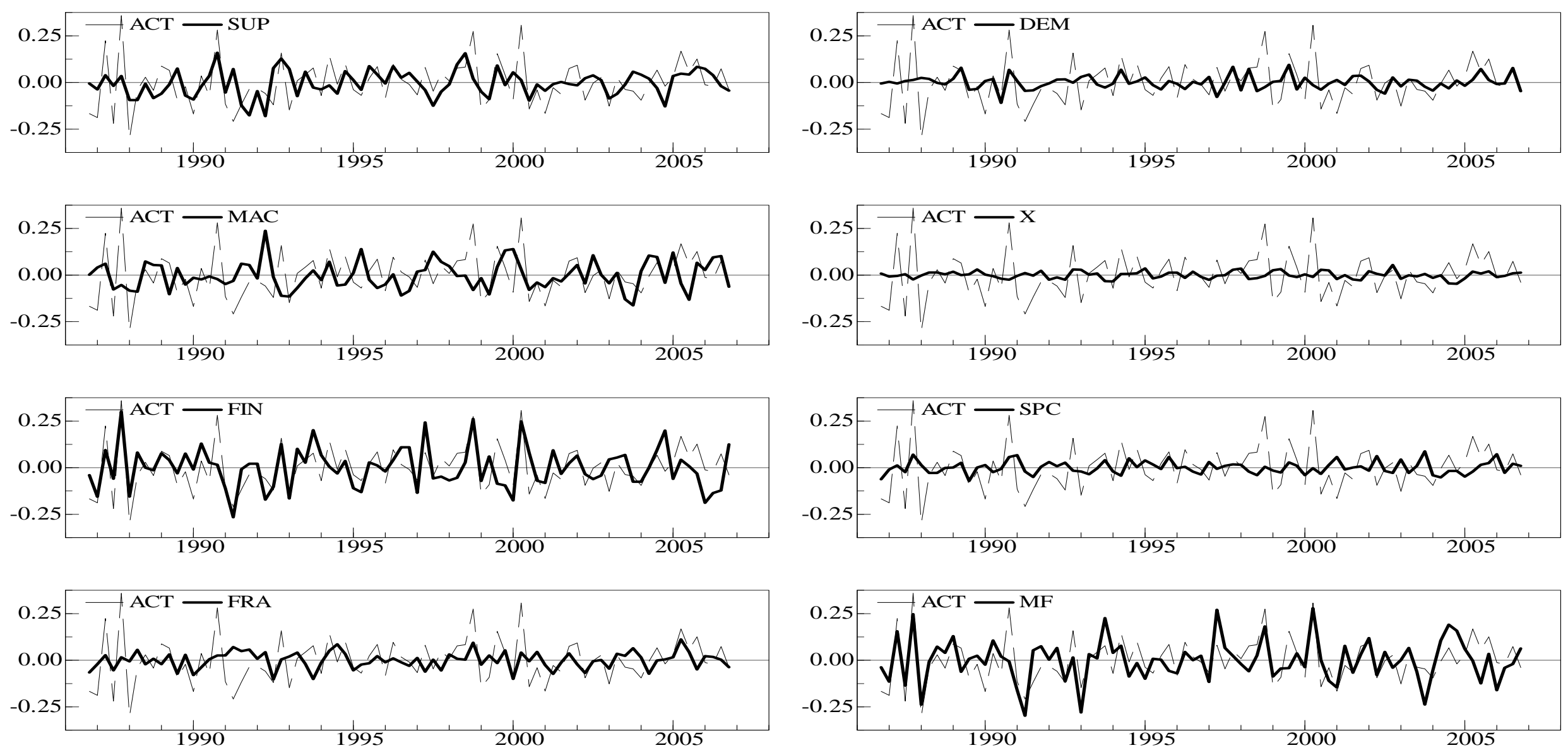

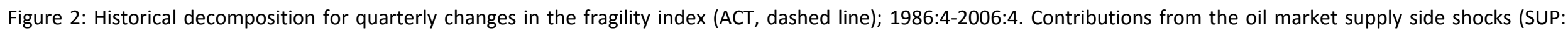

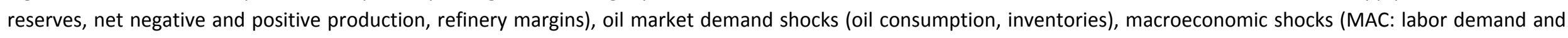

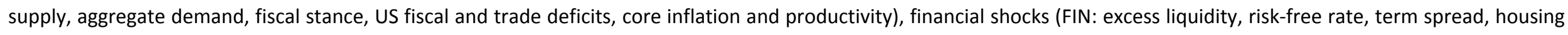

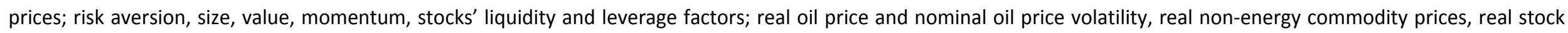

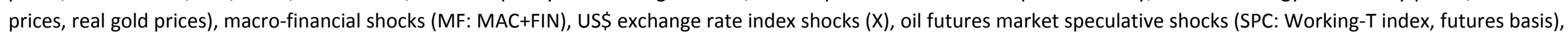
fragility factor own shock (FRA). 

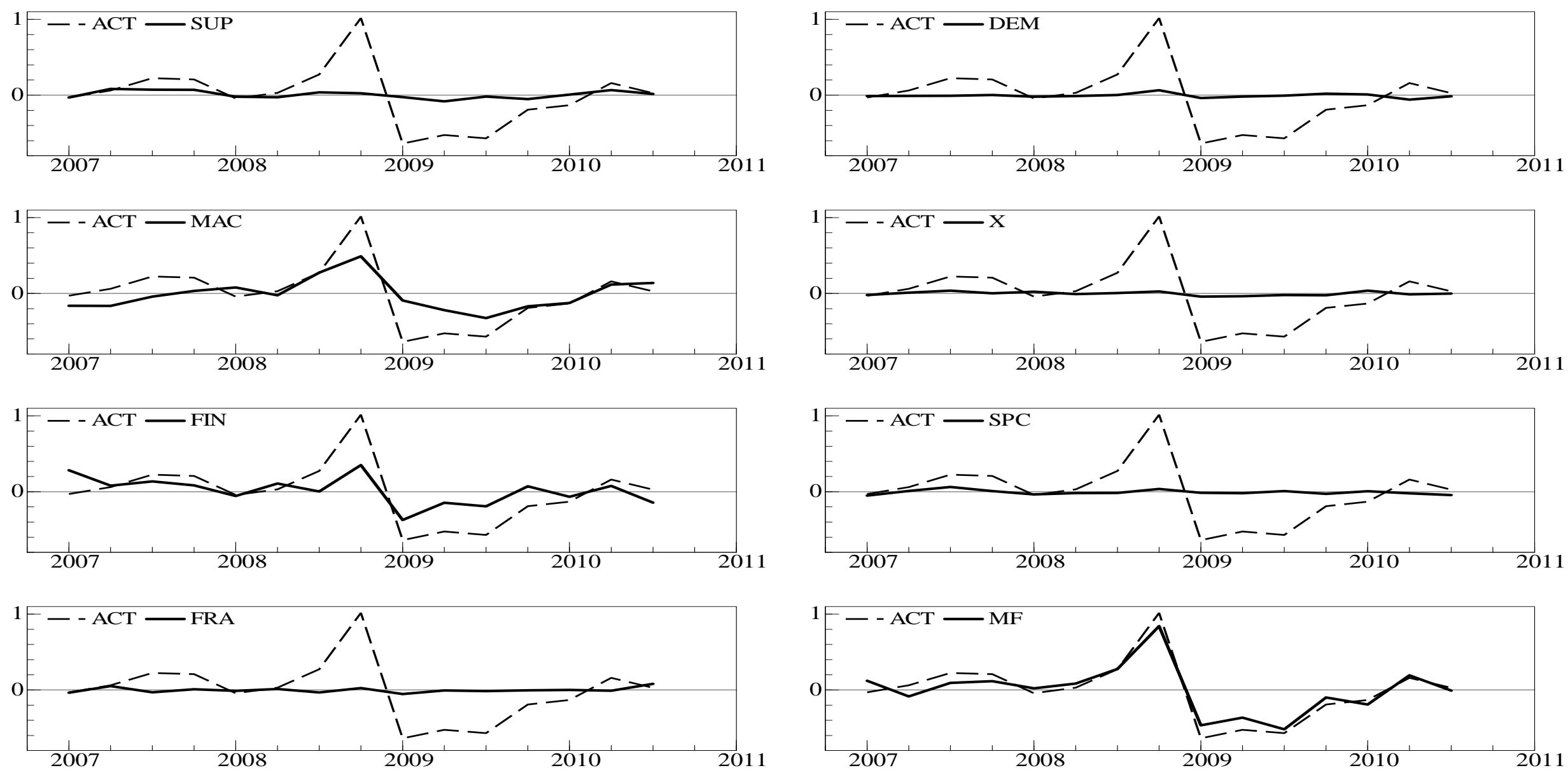

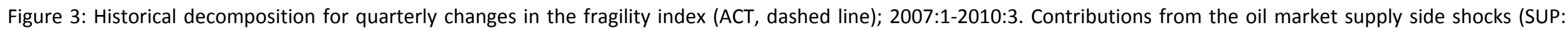

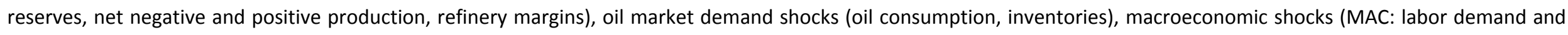

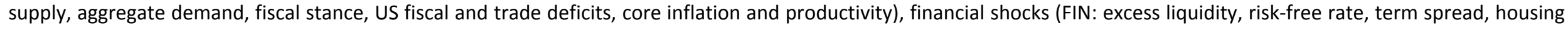

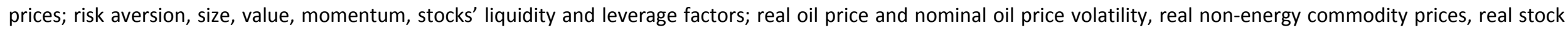

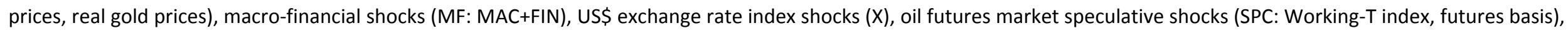
fragility factor own shock (FRA). 

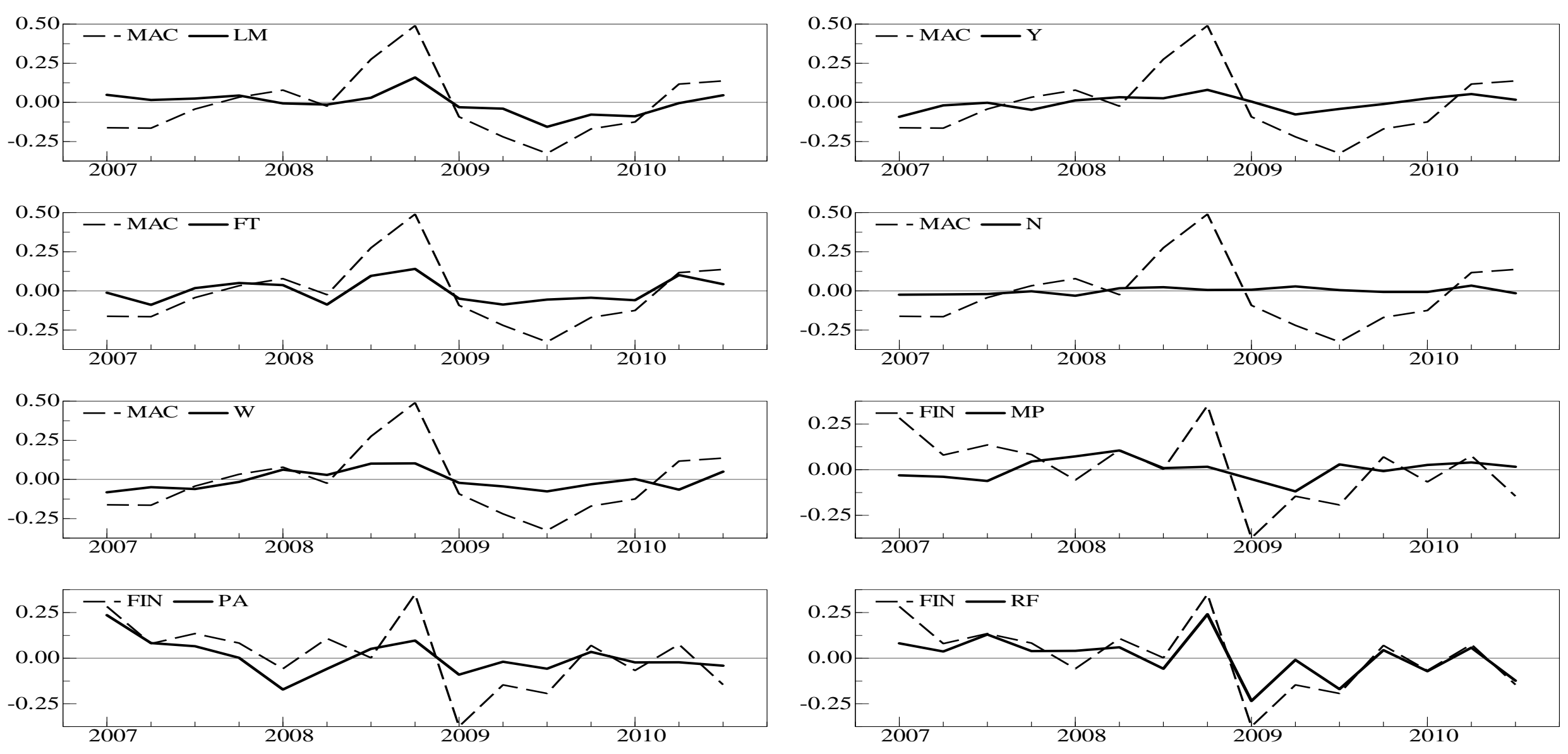

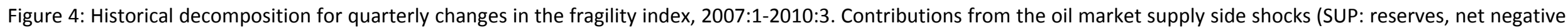

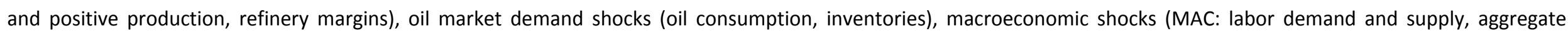

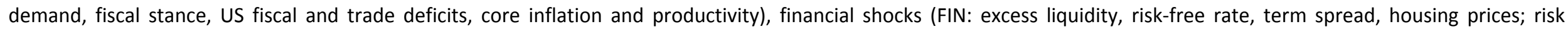

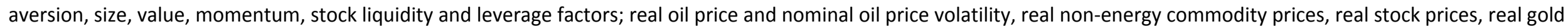

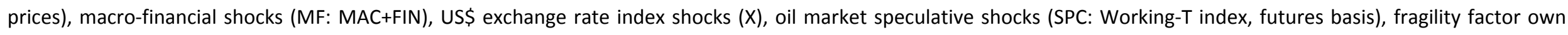
shock (FRA). 

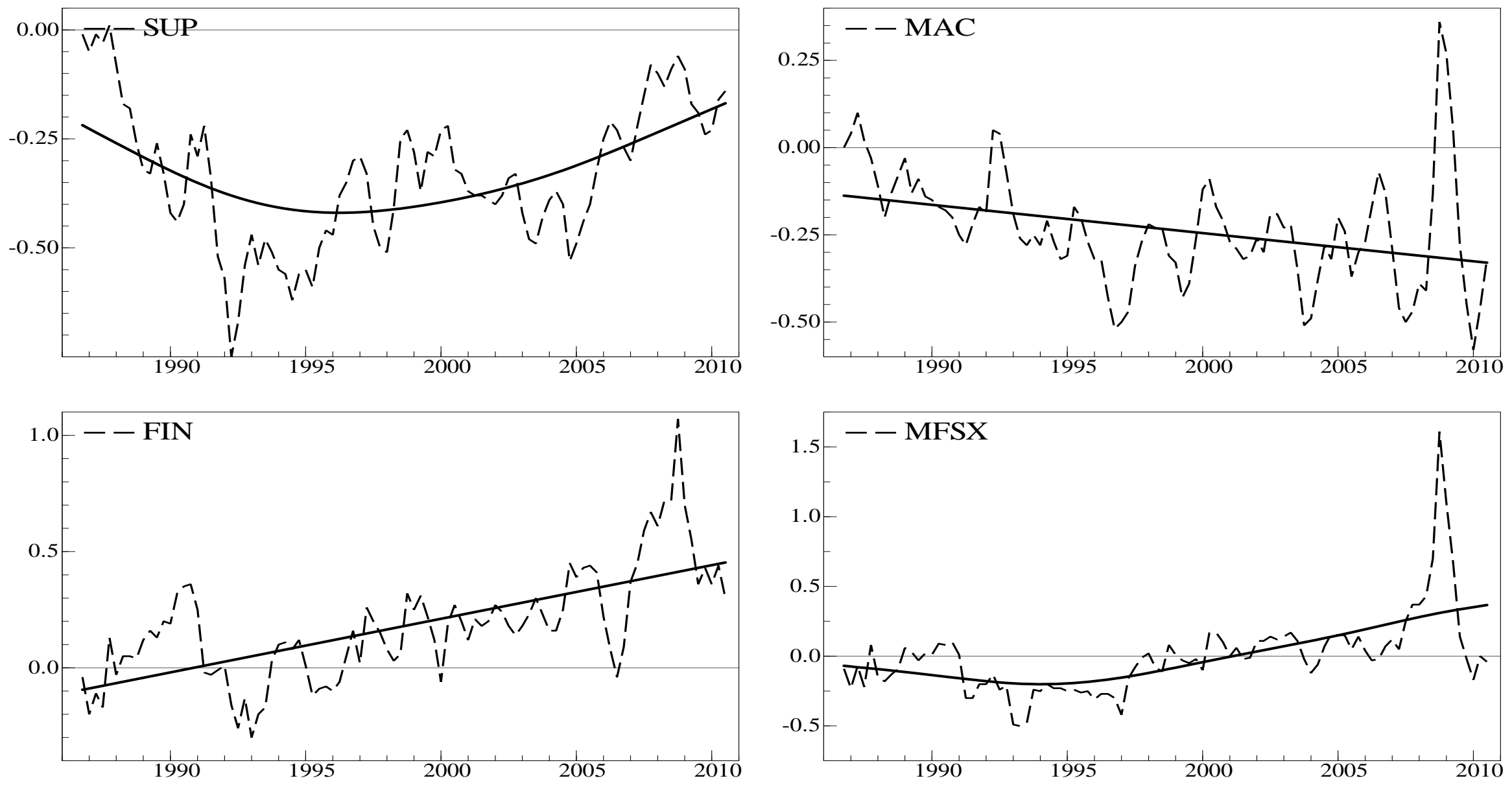

Figure 5: Historical decomposition of the fragility index (dashed line) with spline smoother (solid line); 1986:4-2010:3. Cumulative contributions from the oil market supply side shocks (SUP: reserves, net negative and positive production, refinery margins), macroeconomic shocks (MAC: labor demand and supply, aggregate demand, fiscal stance, US fiscal and trade deficits, core inflation and productivity), financial shocks (FIN: excess liquidity, risk-free rate, term spread, housing prices; risk aversion, size, value, momentum, stocks' liquidity and leverage factors; real oil price and nominal oil price volatility, real non-energy commodity prices, real stock prices, real gold prices), macro-financial shocks (MFSX: MAC+FIN+SPC+X; US\$ exchange rate index shocks (X), oil market speculative shocks (SPC: Working-T index, futures basis). 
Our papers can be downloaded at:

http://cerp.unito.it/index.php/en/publications

\section{CeRP Working Paper Series}

\begin{tabular}{|c|c|}
\hline$N^{\circ} 128 / 12$ & $\begin{array}{l}\text { Fabio Cesare Bagliano } \\
\text { Claudio Morana }\end{array}$ \\
\hline$N^{\circ} 127 / 12$ & $\begin{array}{l}\text { Mariacristina Rossi } \\
\text { Serena Trucchi }\end{array}$ \\
\hline$N^{\circ} 126 / 11$ & $\begin{array}{l}\text { Margherita Borella } \\
\text { Flavia Coda Moscarola } \\
\text { Mariacristina Rossi }\end{array}$ \\
\hline$N^{\circ} 125 / 11$ & Carolina Fugazza \\
\hline$N^{\circ} 124 / 11$ & $\begin{array}{l}\text { Agnese Romiti } \\
\text { Mariacristina Rossi }\end{array}$ \\
\hline$N^{\circ} 123 / 11$ & $\begin{array}{l}\text { Elsa Fornero } \\
\text { Maria Cristina Rossi } \\
\text { Maria Cesira Urzì Brancat }\end{array}$ \\
\hline $\mathrm{N}^{\circ} 122 / 11$ & Serena Trucchi \\
\hline $\mathrm{N}^{\circ} 121 / 11$ & $\begin{array}{l}\text { Elsa Fornero } \\
\text { Chiara Monticone } \\
\text { Serena Trucchi }\end{array}$ \\
\hline $\mathrm{N}^{\circ} 120 / 11$ & $\begin{array}{l}\text { Giovanni Mastrobuoni } \\
\text { Filippo Taddei }\end{array}$ \\
\hline$N^{\circ} 119 / 11$ & $\begin{array}{l}\text { Maarten van Rooij } \\
\text { Annamaria Lusardi } \\
\text { Rob Alessie }\end{array}$ \\
\hline $\mathrm{N}^{\circ} 118 / 11$ & $\begin{array}{l}\text { Luca Beltrametti } \\
\text { Matteo Della Valle }\end{array}$ \\
\hline $\mathrm{N}^{\circ} 117 / 11$ & $\begin{array}{l}\text { Riccardo Calcagno } \\
\text { Chiara Monticone }\end{array}$ \\
\hline $\mathrm{N}^{\circ} 116 / 11$ & $\begin{array}{l}\text { Annamaria Lusardi } \\
\text { Daniel Schneider } \\
\text { Peter Tufano }\end{array}$ \\
\hline$N^{\circ} 115 / 11$ & $\begin{array}{l}\text { Adele Atkinson } \\
\text { Flore-Anne Messy }\end{array}$ \\
\hline $\mathrm{N}^{\circ} 114 / 11$ & $\begin{array}{l}\text { Leora Klapper } \\
\text { Georgios A. Panos }\end{array}$ \\
\hline$N^{\circ} 113 / 11$ & $\begin{array}{l}\text { Diana Crossan } \\
\text { David Feslier } \\
\text { Roger Hurnard }\end{array}$ \\
\hline$N^{\circ} 112 / 11$ & $\begin{array}{l}\text { Johan Almenberg } \\
\text { Jenny Säve-Söderbergh }\end{array}$ \\
\hline$N^{\circ} 111 / 11$ & $\begin{array}{l}\text { Elsa Fornero } \\
\text { Chiara Monticone }\end{array}$ \\
\hline
\end{tabular}

Determinants of US Financial Fragility Conditions

Liquidity Constraints and Labor Supply

(Un)expected retirement and the consumption puzzle

Tracking the Italian employees' TFR over their working life careers

Should we Retire Earlier in order to Look After our Parents? The Role of immigrants

Explaining why, right or wrong, (Italian) households do not like reverse mortgages

How credit markets affect homeownership: an explanation based on differences between Italian regions

The effect of financial literacy on mortgage choices

Age Before Beauty? Productivity and Work vs. Seniority and Early Retirement

Financial Literacy, Retirement Planning, and Household Wealth

Does the implicit pension debt mean anything after all?

Financial Literacy and the Demand for Financial Advice

Financially Fragile Households: Evidence and Implications

Assessing financial literacy in 12 countries: an OECD Pilot Exercise

Financial Literacy and Retirement Planning in View of a Growing Youth Demographic: The Russian Case

Financial Literacy and Retirement Planning in New Zealand

Financial Literacy and Retirement Planning in Sweden

Financial Literacy and Pension Plan Participation in Italy 


\begin{tabular}{|c|c|}
\hline $\mathrm{N}^{\circ} 110 / 11$ & $\begin{array}{l}\text { Rob Alessie } \\
\text { Maarten Van Rooij } \\
\text { Annamaria Lusardi }\end{array}$ \\
\hline$N^{\circ} 109 / 11$ & $\begin{array}{l}\text { Tabea Bucher-Koenen } \\
\text { Annamaria Lusardi }\end{array}$ \\
\hline$N^{\circ} 108 / 11$ & Shizuka Sekita \\
\hline$N^{\circ} 107 / 11$ & $\begin{array}{l}\text { Annamaria Lusardi } \\
\text { Olivia S. Mitchell }\end{array}$ \\
\hline$N^{\circ} 106 / 11$ & $\begin{array}{l}\text { Annamaria Lusardi } \\
\text { Olivia S. Mitchell }\end{array}$ \\
\hline$N^{\circ} 105 / 11$ & Agnese Romiti \\
\hline$N^{\circ} 104 / 11$ & Ambrogio Rinaldi \\
\hline $\mathrm{N}^{\circ} 103 / 10$ & $\begin{array}{l}\text { Fabio Bagliano } \\
\text { Claudio Morana }\end{array}$ \\
\hline$N^{\circ} 102 / 10$ & $\begin{array}{l}\text { Nuno Cassola } \\
\text { Claudio Morana }\end{array}$ \\
\hline$N^{\circ} 101 / 10$ & Tetyana Dubovyk \\
\hline$N^{\circ} 100 / 10$ & $\begin{array}{l}\text { Laura Piatti } \\
\text { Giuseppe Rocco }\end{array}$ \\
\hline No $99 / 10$ & $\begin{array}{l}\text { Fabio Bagliano } \\
\text { Claudio Morana }\end{array}$ \\
\hline$N^{\circ} 98 / 10$ & $\begin{array}{l}\text { Annamaria Lusardi } \\
\text { Daniel Schneider } \\
\text { Peter Tufano }\end{array}$ \\
\hline$N^{\circ} 97 / 10$ & $\begin{array}{l}\text { Carlo Maccheroni } \\
\text { Tiziana Barugola }\end{array}$ \\
\hline$N^{\circ} 96 / 10$ & $\begin{array}{l}\text { Riccardo Calcagno } \\
\text { Mariacristina Rossi }\end{array}$ \\
\hline$N^{\circ} 95 / 10$ & $\begin{array}{l}\text { Flavia Coda Moscarola } \\
\text { Elsa Fornero } \\
\text { Mariacristina Rossi }\end{array}$ \\
\hline$N^{\circ} 94 / 10$ & $\begin{array}{l}\text { John A. List } \\
\text { Sally Sadoff } \\
\text { Mathis Wagner }\end{array}$ \\
\hline$N^{\circ} 93 / 10$ & Mathis Wagner \\
\hline$N^{\circ} 92 / 10$ & $\begin{array}{l}\text { Rob Alessie } \\
\text { Michele Belloni }\end{array}$ \\
\hline No 91/09 & $\begin{array}{l}\text { Annamaria Lusardi } \\
\text { Olivia S. Mitchell } \\
\text { Vilsa Curto }\end{array}$ \\
\hline$N^{\circ} 90 / 09$ & $\begin{array}{l}\text { Annamaria Lusardi } \\
\text { Olivia S. Mitchell }\end{array}$ \\
\hline$N^{\circ} 89 / 09$ & Elena Vigna \\
\hline
\end{tabular}

Financial Literacy, Retirement Preparation and Pension Expectations in the Netherlands

Financial Literacy and Retirement Planning in Germany

Financial Literacy and Retirement Planning in Japan

Financial Literacy and Retirement Planning in the United States

Financial Literacy Around the World: An Overview

Immigrants-Natives Complementarities in Production: Evidence from Italy

Pension awareness and nation-wide auto-enrolment: the Italian experience

The Great Recession: US dynamics and spillovers to the world economy

The 2007-? financial crisis: a money market perspective

Macroeconomic Aspects of Italian Pension Reforms of 1990s

L'educazione e la comunicazione previdenziale - Il caso italiano

The effects of US economic and financial crises on euro area convergence

The Economic Crisis and Medical Care Usage

E se l'aspettativa di vita continuasse la sua crescita? Alcune ipotesi per le generazioni italiane 1950-2005

Portfolio Choice and Precautionary Savings

Parents/children “deals”: Inter-Vivos Transfers and Living Proximity

So you want to run an experiment, now what? Some Simple Rules of Thumb for Optimal Experimental Design

The Heterogeneous Labor Market Effects of Immigration

Retirement choices in Italy: what an option value model tells us

Financial Literacy among the Young:

Evidence and Implications for Consumer Policy

How Ordinary Consumers Make Complex Economic Decisions: Financial Literacy and Retirement Readiness

Mean-variance inefficiency of CRRA and CARA utility functions for portfolio selection in defined contribution pension schemes 


\begin{tabular}{|c|c|}
\hline$N^{\circ} 88 / 09$ & Maela Giofré \\
\hline$N^{\circ} 87 / 09$ & $\begin{array}{l}\text { Elsa Fornero } \\
\text { Annamaria Lusardi } \\
\text { Chiara Monticone }\end{array}$ \\
\hline$N^{\circ} 86 / 09$ & $\begin{array}{l}\text { Margherita Borella } \\
\text { Flavia Coda Moscarola }\end{array}$ \\
\hline $\mathrm{N}^{\circ} 85 / 09$ & $\begin{array}{l}\text { Cathal O’Donoghue } \\
\text { John Lennon } \\
\text { Stephen Hynes } \\
\text { Luca Spataro }\end{array}$ \\
\hline $\mathrm{N}^{\circ} 83 / 09$ & $\begin{array}{l}\text { Annamaria Lusardi } \\
\text { Peter Tufano }\end{array}$ \\
\hline$N^{\circ} 82 / 09$ & $\begin{array}{l}\text { Carolina Fugazza } \\
\text { Massimo Guidolin } \\
\text { Giovanna Nicodano }\end{array}$ \\
\hline$N^{\circ} 81 / 09$ & $\begin{array}{l}\text { Fabio Bagliano } \\
\text { Claudio Morana }\end{array}$ \\
\hline$N^{\circ} 80 / 08$ & Claudio Campanale \\
\hline$N^{\circ} 79 / 08$ & Annamaria Lusardi \\
\hline $\mathrm{N}^{\circ} 78 / 08$ & $\begin{array}{l}\text { Margherita Borella } \\
\text { Giovanna Segre }\end{array}$ \\
\hline $\mathrm{N}^{\circ} 77 / 08$ & $\begin{array}{l}\text { Giovanni Guazzarotti } \\
\text { Pietro Tommasino }\end{array}$ \\
\hline $\mathrm{N}^{\circ} 76 / 08$ & $\begin{array}{l}\text { Riccardo Calcagno } \\
\text { Elsa Fornero } \\
\text { Mariacristina Rossi }\end{array}$ \\
\hline$N^{\circ} 75 / 08$ & $\begin{array}{l}\text { Harold Alderman } \\
\text { Johannes Hoogeveen } \\
\text { Mariacristina Rossi }\end{array}$ \\
\hline$N^{\circ} 74 / 08$ & Maela Giofré \\
\hline$N^{\circ} 73 / 08$ & $\begin{array}{l}\text { Michele Belloni } \\
\text { Rob Alessie }\end{array}$ \\
\hline$N^{\circ} 72 / 08$ & $\begin{array}{l}\text { Annamaria Lusardi } \\
\text { Olivia Mitchell }\end{array}$ \\
\hline$N^{\circ} 71 / 07$ & Flavia Coda Moscarola \\
\hline
\end{tabular}
N 70/07 Radha Iyengar Giovanni Mastrobuoni
N 69/07 Carolina Fugazza Massimo Guidolin Giovanna Nicodano

N 68/07 Massimo Guidolin Giovanna Nicodano
Convergence of EMU Equity Portfolios

Adequacy of Saving for Old Age in Europe

Microsimulation of Pension Reforms: Behavioural versus Nonbehavioural Approach

The Life-Cycle Income Analysis Model (LIAM): A Study of a Flexible Dynamic Microsimulation Modelling Computing Framework

Il sistema previdenziale italiano dallo shock petrolifero del 1973 al Trattato di Maastricht del 1993

Debt Literacy, Financial Experiences, and Overindebtedness

Time and Risk Diversification in Real Estate Investments: Assessing the Ex Post Economic Value

Permanent and Transitory Dynamics in House Prices and Consumption: Cross-Country Evidence

Learning, Ambiguity and Life-Cycle Portfolio Allocation

Increasing the Effectiveness of Financial Education in the Workplace

Le pensioni dei lavoratori parasubordinati: prospettive dopo un decennio di gestione separata

The Annuity Market in an Evolving Pension System: Lessons from Italy

The Effect of House Prices on Household Saving: The Case of Italy

Preschool Nutrition and Subsequent Schooling Attainment: Longitudinal Evidence from Tanzania

Information Asymmetries and Foreign Equity Portfolios: Households versus Financial Investors

The Importance of Financial Incentives on Retirement Choices: New Evidence for Italy

Planning and Financial Literacy: How Do Women Fare?

Women participation and caring decisions: do different institutional frameworks matter? A comparison between Italy and The Netherlands

The Political Economy of the Disability Insurance. Theory and Evidence of Gubernatorial Learning from Social Security Administration Monitoring

Investing in Mixed Asset Portfolios: the Ex-Post Performance

Small Caps in International Diversified Portfolios 


\begin{tabular}{|c|c|}
\hline $\mathrm{N}^{\circ} 67 / 07$ & $\begin{array}{l}\text { Carolina Fugazza } \\
\text { Maela Giofré } \\
\text { Giovanna Nicodano }\end{array}$ \\
\hline$N^{\circ} 66 / 07$ & $\begin{array}{l}\text { Maarten van Rooij } \\
\text { Annamaria Lusardi } \\
\text { Rob Alessie }\end{array}$ \\
\hline$N^{\circ} 65 / 07$ & Annamaria Lusardi \\
\hline$N^{\circ} 64 / 07$ & $\begin{array}{l}\text { Carlo Casarosa } \\
\text { Luca Spataro }\end{array}$ \\
\hline$N^{\circ} 63 / 07$ & Claudio Campanale \\
\hline$N^{\circ} 62 / 07$ & $\begin{array}{l}\text { Margherita Borella } \\
\text { Elsa Fornero } \\
\text { Mariacristina Rossi }\end{array}$ \\
\hline$N^{\circ} 61 / 07$ & Irina Kovrova \\
\hline$N^{\circ} 60 / 07$ & $\begin{array}{l}\text { Riccardo Cesari } \\
\text { Giuseppe Grande } \\
\text { Fabio Panetta }\end{array}$ \\
\hline$N^{\circ} 59 / 07$ & $\begin{array}{l}\text { Riccardo Calcagno } \\
\text { Roman Kraeussl } \\
\text { Chiara Monticone }\end{array}$ \\
\hline$N^{\circ} 58 / 07$ & $\begin{array}{l}\text { Elisa Luciano } \\
\text { Jaap Spreeuw } \\
\text { Elena Vigna }\end{array}$ \\
\hline$N^{\circ} 57 / 07$ & $\begin{array}{l}\text { Giovanni Mastrobuoni } \\
\text { Matthew Weinberg }\end{array}$ \\
\hline$N^{\circ} 56 / 07$ & $\begin{array}{l}\text { John A. Turner } \\
\text { Satyendra Verma }\end{array}$ \\
\hline$N^{\circ} 55 / 06$ & Antonio Abatemarco \\
\hline$N^{\circ} 54 / 06$ & $\begin{array}{l}\text { Annamaria Lusardi } \\
\text { Olivia S. Mitchell }\end{array}$ \\
\hline$N^{\circ} 53 / 06$ & Giovanni Mastrobuoni \\
\hline$N^{\circ} 52 / 06$ & $\begin{array}{l}\text { Luigi Guiso } \\
\text { Tullio Jappelli }\end{array}$ \\
\hline$N^{\circ} 51 / 06$ & Giovanni Mastrobuoni \\
\hline$N^{\circ} 50 / 06$ & $\begin{array}{l}\text { Andrea Buffa } \\
\text { Chiara Monticone }\end{array}$ \\
\hline$N^{\circ} 49 / 06$ & Mariacristina Rossi \\
\hline$N^{\circ} 48 / 06$ & $\begin{array}{l}\text { Onorato Castellino } \\
\text { Elsa Fornero }\end{array}$ \\
\hline
\end{tabular}

International Diversification and Labor Income Risk

Financial Literacy and Stock Market Participation

Household Saving Behavior: The Role of Literacy, Information and Financial Education Programs

(Updated version June 08: "Financial Literacy: An Essential Tool for Informed Consumer Choice?”)

Rate of Growth of Population, Saving and Wealth in the Basic Life-cycle Model when the Household is the Decision Unit

Life-Cycle Portfolio Choice: The Role of Heterogeneous UnderDiversification

Does Consumption Respond to Predicted Increases in Cash-onhand Availability? Evidence from the Italian "Severance Pay"

Effects of the Introduction of a Funded Pillar on the Russian Household Savings: Evidence from the 2002 Pension Reform

La Previdenza Complementare in Italia:

Caratteristiche, Sviluppo e Opportunità per i Lavoratori

An Analysis of the Effects of the Severance Pay Reform on Credit to Italian SMEs

Modelling Stochastic Mortality for Dependent Lives

Heterogeneity in Intra-Monthly Consumption. Patterns, SelfControl, and Savings at Retirement

Why Some Workers Don’t Take 401(k) Plan Offers: Inertia versus Economics

On the Measurement of Intra-Generational Lifetime Redistribution in Pension Systems

Baby Boomer Retirement Security: The Roles of Planning, Financial Literacy, and Housing Wealth

Labor Supply Effects of the Recent Social Security Benefit Cuts: Empirical Estimates Using Cohort Discontinuities

Information Acquisition and Portfolio Performance

The Social Security Earnings Test Removal. Money Saved or Money Spent by the Trust Fund?

Do European Pension Reforms Improve the Adequacy of Saving?

Examining the Interaction between Saving and Contributions to Personal Pension Plans. Evidence from the BHPS

Public Policy and the Transition to Private Pension Provision in the United States and Europe 


\begin{tabular}{|c|c|}
\hline$N^{\circ} 47 / 06$ & $\begin{array}{l}\text { Michele Belloni } \\
\text { Carlo Maccheroni }\end{array}$ \\
\hline$N^{\circ} 46 / 05$ & $\begin{array}{l}\text { Annamaria Lusardi } \\
\text { Olivia S. Mitchell }\end{array}$ \\
\hline$N^{\circ} 45 / 05$ & Claudio Campanale \\
\hline$N^{\circ} 44 / 05$ & Henrik Cronqvist \\
\hline$N^{\circ} 43 / 05$ & $\begin{array}{l}\text { John Beshears } \\
\text { James J. Choi } \\
\text { David Laibson } \\
\text { Brigitte C. Madrian }\end{array}$ \\
\hline$N^{\circ} 42 / 05$ & $\begin{array}{l}\text { Margherita Borella } \\
\text { Flavia Coda Moscarola }\end{array}$ \\
\hline$N^{\circ} 41 / 05$ & $\begin{array}{l}\text { Massimo Guidolin } \\
\text { Giovanna Nicodano }\end{array}$ \\
\hline$N^{\circ} 40 / 05$ & $\begin{array}{l}\text { Carolina Fugazza } \\
\text { Massimo Guidolin } \\
\text { Giovanna Nicodano }\end{array}$ \\
\hline$N^{\circ} 39 / 05$ & Anna Rita Bacinello \\
\hline$N^{\circ} 38 / 05$ & $\begin{array}{l}\text { Carolina Fugazza } \\
\text { Federica Teppa }\end{array}$ \\
\hline$N^{\circ} 37 / 04$ & Jay Ginn \\
\hline$N^{\circ} 36 / 04$ & Laurence J. Kotlikoff \\
\hline$N^{\circ} 35 / 04$ & $\begin{array}{l}\text { Monika Bütler } \\
\text { Olivia Huguenin } \\
\text { Federica Teppa }\end{array}$ \\
\hline$N^{\circ} 34 / 04$ & Chourouk Houssi \\
\hline$N^{\circ} 33 / 04$ & $\begin{array}{l}\text { Elsa Fornero } \\
\text { Carolina Fugazza } \\
\text { Giacomo Ponzetto }\end{array}$ \\
\hline$N^{\circ} 32 / 04$ & $\begin{array}{l}\text { Angelo Marano } \\
\text { Paolo Sestito }\end{array}$ \\
\hline$N^{\circ} 31 / 03$ & Giacomo Ponzetto \\
\hline$N^{\circ} 30 / 03$ & $\begin{array}{l}\text { Bas Arts } \\
\text { Elena Vigna }\end{array}$ \\
\hline$N^{\circ} 29 / 02$ & Marco Taboga \\
\hline$N^{\circ} 28 / 02$ & Luca Spataro \\
\hline$N^{\circ} 27 / 02$ & Reinhold Schnabel \\
\hline$N^{\circ} 26 / 02$ & E. Philip Davis \\
\hline$N^{\circ} 25 / 02$ & $\begin{array}{l}\text { Edmund Cannon } \\
\text { Ian Tonks }\end{array}$ \\
\hline
\end{tabular}

Actuarial Neutrality when Longevity Increases: An Application to the Italian Pension System

Financial Literacy and Planning: Implications for Retirement Wellbeing

Increasing Returns to Savings and Wealth Inequality

Advertising and Portfolio Choice

The Importance of Default Options for Retirement Saving Outcomes: Evidence from the United States

Distributive Properties of Pensions Systems: a Simulation of the Italian Transition from Defined Benefit to Defined Contribution Small Caps in International Equity Portfolios: The Effects of Variance Risk.

Investing for the Long-Run in European Real Estate. Does Predictability Matter?

Modelling the Surrender Conditions in Equity-Linked Life Insurance

An Empirical Assessment of the Italian Severance Payment (TFR)

Actuarial Fairness or Social Justice?

A Gender Perspective on Redistribution in Pension Systems

Pensions Systems and the Intergenerational Distribution of Resources

What Triggers Early Retirement. Results from Swiss Pension Funds

Le Vieillissement Démographique :

Problématique des Régimes de Pension en Tunisie

A Comparative Analysis of the Costs of Italian Individual Pension Plans

Older Workers and Pensioners: the Challenge of Ageing on the Italian Public Pension System and Labour Market

Risk Aversion and the Utility of Annuities

A Switch Criterion for Defined Contribution Pension Schemes

The Realized Equity Premium has been Higher than Expected: Further Evidence

New Tools in Micromodeling Retirement Decisions: Overview and Applications to the Italian Case

Annuities in Germany before and after the Pension Reform of 2001

Issues in the Regulation of Annuities Markets

The Behaviour of UK Annuity Prices from 1972 to the Present 


\begin{tabular}{|c|c|c|}
\hline$N^{\circ} 24 / 02$ & $\begin{array}{l}\text { Laura Ballotta } \\
\text { Steven Haberman }\end{array}$ & Valuation of Guaranteed Annuity Conversion Options \\
\hline$N^{\circ} 23 / 02$ & Ermanno Pitacco & Longevity Risk in Living Benefits \\
\hline$N^{\circ} 22 / 02$ & $\begin{array}{l}\text { Chris Soares } \\
\text { Mark Warshawsky }\end{array}$ & $\begin{array}{l}\text { Annuity Risk: Volatility and Inflation Exposure in Payments } \\
\text { from Immediate Life Annuities }\end{array}$ \\
\hline$N^{\circ} 21 / 02$ & $\begin{array}{l}\text { Olivia S. Mitchell } \\
\text { David McCarthy }\end{array}$ & Annuities for an Ageing World \\
\hline$N^{\circ} 20 / 02$ & Mauro Mastrogiacomo & Dual Retirement in Italy and Expectations \\
\hline$N^{\circ} 19 / 02$ & $\begin{array}{l}\text { Paolo Battocchio } \\
\text { Francesco Menoncin }\end{array}$ & $\begin{array}{l}\text { Optimal Portfolio Strategies with Stochastic Wage Income and } \\
\text { Inflation: The Case of a Defined Contribution Pension Plan }\end{array}$ \\
\hline$N^{\circ} 18 / 02$ & Francesco Daveri & $\begin{array}{l}\text { Labor Taxes and Unemployment: a Survey of the Aggregate } \\
\text { Evidence }\end{array}$ \\
\hline $\mathrm{N}^{\circ} 17 / 02$ & $\begin{array}{l}\text { Richard Disney and } \\
\text { Sarah Smith }\end{array}$ & $\begin{array}{l}\text { The Labour Supply Effect of the Abolition of the Earnings Rule } \\
\text { for Older Workers in the United Kingdom }\end{array}$ \\
\hline$N^{\circ} 16 / 01$ & $\begin{array}{l}\text { Estelle James and } \\
\text { Xue Song }\end{array}$ & $\begin{array}{l}\text { Annuities Markets Around the World: Money’s Worth and Risk } \\
\text { Intermediation }\end{array}$ \\
\hline$N^{\circ} 15 / 01$ & Estelle James & $\begin{array}{l}\text { How Can China Solve ist Old Age Security Problem? The } \\
\text { Interaction Between Pension, SOE and Financial Market Reform }\end{array}$ \\
\hline$N^{\circ} 14 / 01$ & Thomas H. Noe & Investor Activism and Financial Market Structure \\
\hline$N^{\circ} 13 / 01$ & Michela Scatigna & Institutional Investors, Corporate Governance and Pension Funds \\
\hline$N^{\circ} 12 / 01$ & Roberta Romano & $\begin{array}{l}\text { Less is More: Making Shareholder Activism a Valuable } \\
\text { Mechanism of Corporate Governance }\end{array}$ \\
\hline$N^{\circ} 11 / 01$ & $\begin{array}{l}\text { Mara Faccio and Ameziane } \\
\text { Lasfer }\end{array}$ & $\begin{array}{l}\text { Institutional Shareholders and Corporate Governance: The Case } \\
\text { of UK Pension Funds }\end{array}$ \\
\hline$N^{\circ} 10 / 01$ & $\begin{array}{l}\text { Vincenzo Andrietti and Vincent } \\
\text { Hildebrand }\end{array}$ & $\begin{array}{l}\text { Pension Portability and Labour Mobility in the United States. } \\
\text { New Evidence from the SIPP Data }\end{array}$ \\
\hline $\mathrm{N}^{\circ} 9 / 01$ & Hans Blommestein & $\begin{array}{l}\text { Ageing, Pension Reform, and Financial Market Implications in } \\
\text { the OECD Area }\end{array}$ \\
\hline$N^{\circ} 8 / 01$ & Margherita Borella & $\begin{array}{l}\text { Social Security Systems and the Distribution of Income: an } \\
\text { Application to the Italian Case }\end{array}$ \\
\hline$N^{\circ} 7 / 01$ & Margherita Borella & $\begin{array}{l}\text { The Error Structure of Earnings: an Analysis on Italian } \\
\text { Longitudinal Data }\end{array}$ \\
\hline$N^{\circ} 6 / 01$ & Flavia Coda Moscarola & $\begin{array}{l}\text { The Effects of Immigration Inflows on the Sustainability of the } \\
\text { Italian Welfare State }\end{array}$ \\
\hline$N^{\circ} 5 / 01$ & Vincenzo Andrietti & $\begin{array}{l}\text { Occupational Pensions and Interfirm Job Mobility in the } \\
\text { European Union. Evidence from the ECHP Survey }\end{array}$ \\
\hline$N^{\circ} 4 / 01$ & Peter Diamond & Towards an Optimal Social Security Design \\
\hline$N^{\circ} 3 / 00$ & $\begin{array}{l}\text { Emanuele Baldacci } \\
\text { Luca Inglese }\end{array}$ & $\begin{array}{l}\text { Le caratteristiche socio economiche dei pensionati in Italia. } \\
\text { Analisi della distribuzione dei redditi da pensione (only available } \\
\text { in the Italian version) }\end{array}$ \\
\hline$N^{\circ} 2 / 00$ & $\begin{array}{l}\text { Pier Marco Ferraresi } \\
\text { Elsa Fornero }\end{array}$ & $\begin{array}{l}\text { Social Security Transition in Italy: Costs, Distorsions and (some) } \\
\text { Possible Correction }\end{array}$ \\
\hline $\mathrm{N}^{\circ} 1 / 00$ & Guido Menzio & Opting Out of Social Security over the Life Cycle \\
\hline
\end{tabular}


